\title{
The Worship of Celestial Bodies in Japan: Politics, Rituals and Icons
}

\section{Lucia Dolce}

Interest in the movements of stars and other celestial bodies, as well as belief in their relevance in human affairs, characterized traditional cultures worldwide, and Japan was no exception. In pre-modern Japan astronomy and astrology were equally regarded as science and required specialists able to identify the course of the stars and to decode its consequences in the life of the state and of individuals. Japanese society inherited and developed Chinese theories on the heavens, as well as Chinese divinatory arts: in this complex system of thought celestial events corresponded to terrestrial matters, and the preoccupation with interpreting changes in the heavens was seriously undertaken to avoid unwanted changes and misfortune on earth. Celestial bodies underwent a process of deification, producing an extensive ritual apparatus and iconographic patterns to represent and venerate the stars, and thus providing a way to weaken their negative influences on human beings.

\section{Astral sites, astral deities}

Evidence of the religious meaning of celestial bodies and their impact on different fields of the political and cultural life of the country abounds in historical, literary and visual sources, as well as in the physical structure of cities. Walking today around Kyoto, the old capital of Japan, one still comes across a number of sites that have been connected to stars for centuries: a few have lost the memory of the astrological dimension of their cultic practices, but most have maintained it. Some have acquired new associations, following the recent explosion of interest in astrology which characterized the beginning of the current century in Japan.

The geomantic orientation of Kyoto is immediately perceivable by looking at a map of the city, which was built after the pattern of Changan 長安, the capital of Tang 唐 China. The centre of the city, represented by the imperial palace, embodied the middle, the most important of the

Lucia Dolce, 'The Worship of Celestial Bodies in Japan: Politics, Rituals and Icons', Culture And Cosmos, Vol. 10 no 1 and 2, Spring/Summer and Autumn Winter 2006, pp. 3-43.

www.CultureAndCosmos.com 
4 The Worship of Celestial Bodies in Japan

five Chinese cardinal points, corresponding in the sky to the Pole Star. The other four directions, which were indicated in the sky by groupings of equatorial constellations, were represented by heraldic animals and were marked by specific sacred places that were thought to protect the centre from evil coming from the four directions (Fig. 1). The Chinese symbol of the North, for instance, a tortoise intertwined with a snake (genbu 玄武), corresponds to Funaokayama, a hill which stood directly north of the palace before the latter was moved to the current location, and on which propitiatory rituals were originally performed by Yin-yang specialists. ${ }^{1}$ To the north-east, a direction known as kimon 鬼門 ('gate of demons'), the city is also protected by the imposing site of Mt Hiei, an important Buddhist centre established at roughly the same time as the capital. Religious places devoted to astral deities are found throughout the city, testifying to the variety of practices related to the stars that characterized Japanese culture. Here I will present a few of these representative cultic sites and their deities.

\section{The Great General of Directions}

Hidden away in a narrow shopping street in the Western area of Kyoto is a small shrine which, according to the inscription on the gate, is dedicated to the 'Great General' (Daishōgun 大将軍) ${ }^{2}$ (Figs. 2a-b). Said to have been founded in 794, this shrine was one of the four worshipping halls dedicated to this deity, which were established around the capital to prevent sickness and other calamities from entering the city. Daishōgun Shrine, located northwest of the imperial palace, protected this direction. ${ }^{3}$ But who is the deity venerated there?

1 Even today Funaokayama represents the northern direction in Kyoto geomancy, as seen in the map of Fig. 1. The other directions are marked by a blue dragon (seiryo 青龍) in the East, a white tiger (byakko 白虎) in the South, and a red bird (suzaku 朱雀) in the West.

2 The official name of the shrine today is Daishōgun hasshinsha 大将軍八神社, 'Shrine of the eight Daishōgun deities.' The eight deities personify the eight directions (the four cardinal points and the intermediate directions). For their identification, see Murai Yasuhiko 村井康彦, 'Daishōgun hachijinja,' in Daishōgunshaseki hakkutsu chōsa hōkoku 大将軍社跡一発掘調査報告, Kyoto: Rokushōji kenkyūkai, 1973.

Culture and Cosmos 
Daishōgun was one of the astral gods known as 'ambulant deities' (yugyojin 遊行神), who represented directional interdictions (kata-imi 方忌) concerning specific times of the year. In the Chinese astrological system there were different kinds of interdictions: some were of a permanent nature and concerned everyone, such as the taboos related to the northeast; others affected each individual in different years of his or her life; and yet others applied to everyone but only for a limited time. A number of actions were to be avoided during certain periods of the year. Travelling was the activity most affected, but these temporary interdictions also related to the construction or maintenance of buildings, which were thought to cause a 'violation of the earth'. Measures to escape the consequences of the interdiction, called kata-tagae 方違元, were taken preventively: they were based not on the observation of astrophysical movements, but on the knowledge of the invisible movements of certain astral deities, who came from their usual abodes in the skies to the earth, according to a fixed calendar. There were five major 'ambulant deities': the Pole Star, the planet Venus, Daishōgun, the Spirit of Metal (Konjin 金神), and the personification of the power of the Five Elements. ${ }^{4}$

The deities who caused the interdictions were not abstract entities, but were conceived as objects of devotion for whom specific iconographic representations were created. A concrete building at the back of the main hall of the Daishōgun Shrine houses a small museum where a hundred statues of Daishoggun are assembled, mostly dating from the tenth to the twelfth century, when worship of this astral deity was at its height. They represent Daishōgun in a variety of iconographic styles: in the guise of a warrior, wearing armour and holding a sword with his left hand, while the

3 The other three shrines are more difficult to identify as they do not always correspond to the names and exact locations given in pre-modern sources. In the northern direction we find a Daishōgun Shrine within the precincts of today's Imamiya 今宮 Shrine; in the East the Daishōgun Shrine of Higashi sanjō 東三条, which in ancient sources is indicated as 'Okazaki Daishōgun' 岡崎大将軍; located in the South is the Daishōgun shrine within the precincts of Fujinomori Shrine 藤森神社. See Ibid.

4 For an in-depth analysis of directional interdictions in pre-modern Japan, see the excellent study by Bernard Frank, Kata-imi et kata-tagae. Etude sur les interdits de direction à l’Ėpoque Heian, Paris: Collége de France, 1998 (rev. ed, $1^{\text {st }}$ ed. 1958). 
6 The Worship of Celestial Bodies in Japan

right hand makes a mudra called 'sword mudra' (ken-in 剣印); as a court official, holding a mace (shaku 第) with both hands; as a child; either standing, or seated, often in a half lotus position (hankaza) with one leg pending, a posture similar to that of the bodhisattva Miroku 弥勒 5 (Fig. $3)$. One possible explanation for the survival of such a large number of kami images (shinzo $\bar{o}$ 神像) is that they were presented to the shrine by people who had violated the directional taboos and then had propitiatory rituals performed to Daishōgun, repeating the ritual donations a number of times within a certain period.

Propitiation from the god of directions enshrined here is still sought for in such activities as moving, building a house and travelling, although today's worshippers no longer feel it necessary to offer statues of Daishōgun to the shrine. The shrine sells a wide range of 'cosmological' amulets that ward off evil coming from the 'eight directions' and from inevitable unlucky geomantic arrangements (Figs. 4a-b). Protective talismans are also dedicated to other major deities who affect directional taboos; remarkable examples are Konjin and Toshitokujin 歳徳神 (Fig. 5), for whom a small worshipping hall has been established within the precincts of this shrine. ${ }^{6}$

The Daishōgun Shrine thus testifies to the persistence of traditional beliefs about specific stellar bodies and contributes to the understanding of Japanese astrological culture as manifested in artistic and devotional terms. It also offers material which may be used to explore the changing

5 The images are discussed in a catalogue published on the occasion of an exhibition of the shrine treasures at the Kyoto National Museum: Daishogun shinzō to shashi 大将軍神像と社史 [Images of the God Daishōgun and the History of His Shrine], Kyoto: Daishōgun hasshinsha, 1985. I am most grateful to the current head priest of the shrine who, during my fieldwork in April 2004, opened the Treasure Hall at a time of the year when it is not accessible to the public; showed me artefacts stored away, allowing me to take pictures; and provided me with a copy of this rare catalogue. Seventy-nine statues are listed as Important Cultural Property. One statue was also on display in London a few years ago, in the exhibition on Shinto art held at the British Museum. See Shintō, the Sacred Art of Ancient Japan, Victor Harris, ed., London: British Museum Press, 2001, pp. 142-3. The Treasure Hall is opened only once a year, in the first week of November.

6 On these two deities, see Breen's contribution in this volume.

Culture and Cosmos 
knowledge of the skies through the centuries. For instance, on the second floor of the small museum other artefacts related to astronomy are displayed, and among them are a thirteenth-century rubbing of a Chinese stele representing a map of the sky (tenmonzu 天文図), a Japanese Buddhist chart of the Big Dipper in the form of a dragon (Fig. 6), and a celestial globe made by Shibusawa Shinkai (1639-1715), the famous astronomer who devised the first properly Japanese calendar. ${ }^{7}$

\section{The Bodhisattva of the Cosmic Space}

Major Buddhist establishments have also been centres of worship of celestial bodies in a deified form. Although the rise of esoteric Buddhism is considered responsible for the development of the Buddhist cult of the stars, in fact the practice of associating stars and planets with Buddhas and Bodhisattvas existed in China before the rise of Tantric (or Esoteric) Buddhism. In the Tiantai exegesis of the Lotus Sutra, for instance, three celestial deities appearing in the introductory chapter of the scripture are identified as Buddhist deities, the Sun Deva (Nitten 日天, Skr. Candra), Venus (Myōjō 明星, Skr. Aruna) and the Moon Deva (Gatten 月天, Skr. Sūrya), and are considered to be, respectively, manifestations (ōsa 応作) of the bodhisattvas Daiseishi 大勢至 (Skr. Mahāsthāmaprāpta), Kokūzō 虚空蔵 (Skr. Ākāśagarbha) and Kannon 観音 (Skr. Avalokiteśvara). ${ }^{8}$

Kokūzō, whose name means 'repository of space,' symbolized the universe in terms of cosmic space. This bodhisattva was understood to be the ruler of all stars, an aspect that pictorial icons illustrated by depicting him inside a moon disk said to represent the brightness of Venus, with the deities embodying the seven stars of the Big Dipper, planets and other

\footnotetext{
7 It may be of interest to note, albeit unrelated to Daishōgun, that this shrine also celebrates a popular 'star festival', Tanabata 七夕, which commemorates the mythical encounter of two stars, Shokujosei 織女星 (Vega) and Kengyūsei 牽牛星 (Altair) across the Milky Way. Fig. 2a shows the symbol of the festival, a freshly cut bamboo that on July 7th is placed at the entrance of shrines and upon which worshippers tie strips of paper containing their wishes to the stars. This festival is celebrated in other Shinto shrines in Kyoto, and elsewhere in Japan. On the origins of Tanabata see Kanezashi Shōzō 金指正三, Hoshi uranai, hoshi matsuri 星占い星祭り [Predicting through the stars, venerating the stars], Tokyo: Seiabō, 1974, pp. 122-26.
}

8 Fahua wenju 法華文句, by Zhiyi 智顗. T. 34, no. 1718, p. 24a. 
luminaries depicted above and below him. ${ }^{9}$ Kokūzō was the focus of one of the oldest institutionalized cult of astral bodies in Japanese Buddhism. Several hills in the central and eastern regions of Japan were centres of a

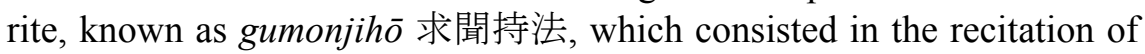
the mantra of Kōkuzō one million times during an allocated period of time, and culminated in an experience of cosmic space through union with the deity in its form as the morning star. Performed in Japan since the Nara period as a practice believed to strengthen monks' ability to remember scriptures, it was one of the most popular private rituals for high ranking clerics, who used to go from their temples in the city to the mountains in order to achieve 'natural wisdom' (jinenchi 自然智) through performance of this ritual. Practitioners included famous figures such as Kūkai 空海 (774-835), Saichō 最澄 (767-822) and Nichiren 日蓮 $(1222-1282) .{ }^{10}$ Their accounts of the gumonjiho emphasized the apparition of the planet Venus in the guise of the celestial deity Myōjō, at the end of the rite. Venus was known in Buddhism as the 'morning star,' after its periodic, bright, pre-dawn appearance. Further, it was considered as a symbol of awakening because it was said to be the star that Sakyamuni saw at the moment of his enlightenment.

One of the most ancient sites of the practice of the gumonjiho in Kyoto is the Hōrinji 法輪寺, a temple in the hills of Saga (West Kyoto), said to have been founded in the early eighth century by Gyōki 行基 (Fig. 7). It was restored by a disciple of Kūkai, Dōshō 道昌 (798-875), who also had visions of Venus after performing the ritual. Known as one of the three great Kokūzō sites of Japan, on the altar it enshrines, together with an image of Kokūzō, a statue of Myōjō. In the Kantō area Kiyosumidera 清澄寺, hidden away in the mountains of the Bōsō peninsula, east of Tokyo, is cited in several medieval ritual documents as an important centre for the performance of this ritual, where well-known monks from

9 See, for instance, the late-Muromachi period painting of Kokūzō in the Boston Museum of Arts, in Izumi Takeo 泉武夫執, Kokūzo bosatsu zo 虚空蔵菩薩像 [Icons of the Bodhisattva Kokūzō], Nihon no bijutsu 380, 1998, p. 67.

10 Sonoda Kōyū 園田香融, Heian bukkyō no kenkyū 平安仏教の研究, Kyoto: Hōzōkan, 1981, pp. 27-52. 
various parts of Japan went to practise ${ }^{11}$ (Fig. 8). The gumonjiho is still performed today as a meditative practice in Tantric Buddhism, in a few temples that are situated in natural settings that allow contemplation of the sky. Inside the hall where the practice is carried out hangs a painting of the bodhisattva Kokūzō, the focus of this meditation. The hall, however, is built in such a way that the practitioner can see the stars through a special window, and thus his meditation can also focus on the planet Venus itself, when visible. ${ }^{12}$

\section{The Bodhisattva of the Northern Pole}

Several of the temple complexes dedicated to Kokūzō include a second hall of worship, often at the top of the hill or mountain behind the main hall, where another deity related to the heavens is venerated: the bodhisattva Myōken 妙見, personification of the Pole Star (hokkyokusei 北極星 or hokushin 北辰) and of the Big Dipper (hokutosei 北斗星 or hokuto shichisei 北斗七星). ${ }^{13}$ In ancient Chinese thought, the Pole Star, apparently immobile at the centre of the northern hemisphere, embodied the Heavenly Emperor. Accordingly, it became a symbol of and metaphor for the sovereign on earth, in China as well in Japan, and object of royal rituals at court. At New Year the emperor himself invoked the Big Dipper, before paying homage to heaven and earth and the four

11 Kiyosumidera (also known with the reading of Seichōji), had different sectarian affiliations throughout the centuries and was headed by an imperial prince during the Tokugawa period. Today it belongs to the Nichiren denomination, because this was the place where Nichiren practiced the gumonjiho in mid-thirteenth century. For details on the medieval practices of Kokūzō at Kiyosumidera, see L. Dolce, 'Esoteric Patterns in Nichiren's Interpretation of the Lotus Sutra,' PhD dissertation, Leiden University, 2002, pp. 56-73.

12 A description of today's practice by a Shingon monk may be found in Taikō Yamazaki, Shingon: Japanese Esoteric Buddhism, Boston \& London: Shambhala, 1988, pp. 185-90.

13 There is a Myōkengū in the hill behind Kiyosumidera. For other examples, see Sano Kenji 佐野賢治, Kokūzō bosatsu shinkō no kenkyū 虚空蔵菩薩信仰の研究 [Studies on the Cult of the Bodhisattva Kokūzō], Tokyo: Yoshikawa kōbunkan, 1996, pp. 258-61. The relation between Kokūzō and Myōken needs further study. 
directions. ${ }^{14}$ The robes that he wore during his accession abhiseka (sokui kanjo 即位灌頂), an initiation ceremony conducted according to Tantric ritual, were decorated with the seven stars of the Big Dipper on the back, while the sun and moon were depicted in the front - a composition signifying the central power of which the emperor was the repository. First worn in Japan by Emperor Shōmu 聖武 in 732, this robe continued to be used for centuries; Emperor Kōmei 孝明 was the last to wear it, in $1874 .^{15}$

In Japan the Pole Star also became an important deity within Esoteric Buddhism, and from the Heian period (794-1180) onwards it was venerated under various names in complex rituals that were originally aimed at protection of the state. ${ }^{16}$ Later, however, its worship spread outside the context of the aristocratic and military elite and assumed more popular forms. It is this last aspect that I would like to explore here.

As the bodhisattva Myōken, the Pole Star still has several sites of worship in the old capital. Many halls dedicated to this deity exist within the precincts of temples belonging to a specific Buddhist denomination, the Nichiren school, which from the late medieval period onwards adopted Myōken as one of its most important protective deities ${ }^{17}$ (Figs. 9-

14 See Kanezashi, op.cit., p. 183 and p. 199. The emperor started the rite by reciting the name of one of the seven stars of the Big Dipper, the one which was associated with the Zodiac sign of that year. This was known as the 'Year star' (tōnen zokusei 当年属星). For a canonical source on the association of the seven stars of the Dipper with the twelve Zodiac signs see Meri Arichi's contribution to this volume.

15 A description of these robes, know as the konben jūni sho 衰冕十二章, may be found in Matsumoto Ikuyo 松本郁代, Chūsei ōken to sokui kanjō 中世王権と即位灌頂, Tokyo: Shinwansha, 2005, pp. 298-338, which includes photographs of a set of the imperial robes kept at the Imperial Household Agency.

16 For an outline of the identity and iconography of the Pole Star in esoteric Buddhism, see the essay by Tsuda Tetsui in this volume.

17 Nomura Yōshō 野村耀昌, 'Kindai ni okeru Myōken shinkō', 近代における妙見信仰, 'in Mochizuki Kankō 望月歓厚, ed., Kindai Nihon no

Culture and Cosmos 
11). At these institutions rituals to the Pole Star, or the Big Dipper, are still part of the monthly liturgical calendar. The cult of Myōken seems to have enjoyed some independence, though, and the shrines devoted to him were opened to believers of all backgrounds. In Kyoto a pilgrimage of twelve sites dedicated to Myōken, and associated with the twelve Zodiac signs, was developed in the mid-Tokugawa period (1600-1868) and it is still carried out today (Fig. 12). The pilgrim starts the route from the temple representing one's own Zodiac sign, or the Zodiac sign of the current year, and visits one temple each month. Most of the sites perform liturgies on the first day of the month, and some perform liturgies also on the fifteenth day. Interestingly, the benefits that are gained through this pilgrimage to Myōken shrines include averting problems connected to directions, house construction or rebuilding, and moving. ${ }^{18}$ In other words, the pilgrim acquires a type of protection similar to that offered by such astral deities as Daishōgun. Although the pilgrimage is today associated with the Nichiren denomination, not all the sites are temples belonging to that denomination, nor is their origin rooted in populist belief. The shrine dedicated to Myōken of the sign of the Rabbit ( $u$ 卯), for example, belongs to Reikanji 霊鑑寺, an imperial convent in Shishigatani, the eastern area of Kyoto, which is today affiliated with the Zen school. (Fig. 13) According to the current abbess, this shrine was established in the late Tokugawa period by the fourth abbess of Reikanji, the younger sister of emperor Kōkaku 光格 (r.1779-1817), to protect the imperial palace in the eastern direction.

Other sites dedicated to this important deity defy modern distinctions between Buddhism and Shinto. In the Kantō area a famous place for the worship of Myōken is Chichibu Shrine 秩父神社 in Saitama prefecture, north of Tokyo. The shrine was known as the Chichibu Myōkengū before the separation of buddha-and-kami related practices that took place during the Meiji period. The deity officially venerated today, Ame no minaka nushi no kami 天之御中主神, is said to be ontologically related to Myōken; indeed, his name signifies his position at the centre of the celestial universe, a position which Myōken/Pole Star also occupies. Chichibu shrine still celebrates a grand star festival in Myōken's honour

Hokke bukkyō 近代日本の法華仏教 [Lotus Buddhism in Early Modern Japan], Kyoto: Heirakuji shoten, 1968, pp. 201-46.

18 These benefits are listed in a pamphlet describing the pilgrimage route. 
12 The Worship of Celestial Bodies in Japan

on the night of December 3 (myōkensai 妙見祭). It is to this shrine that scientists of Japan's Space Development Agency went to petition the lord of the stars to propitiate their success in launching the first Japanese satellite in $1970 .^{19}$

\section{The court astrologer}

A few blocks northwest of the Daishōgun shrine, on a busy thoroughfare of Kyoto, another small shrine attests to the transformations that traditional belief has undergone due to the new boom in astrology and divination: the Seimei Shrine 晴明神社 (Fig. 14a-b). It is dedicated to Abe no Seimei 安倍晴明 (921-1005), one of the onmyōji 陰陽師 (Yinyang specialists) at the service of the Heian court, who provided the Court information on the stars, divination and rituals of exorcism. Because of his legendary power to control spirits, Seimei was soon deified and transformed into the figure of a spiritual master capable of staving off diseases and death. ${ }^{20}$

The Seimei Shrine was established only two years after Seimei's death, allegedly on the site of his residence (although historical records suggest that the latter was in a different part of the city). Today it has become a tourist attraction popular with young people, thanks to a large number of novels, comics, television series and films that have been recently produced on the figure of Seimei, assuring him a place in the world of media and subculture. ${ }^{21}$ The five-pointed star (gobōsei 五芒星), which represents the five elements and their interaction (the 'five phases' of the Yin-yang system), and which was also used in exorcism, has become a symbol of Seimei's skills as an astrologer and, at the same time, a symbol of power that wards off evil. It can be seen everywhere in the shrine

19 Sakurai Katsunoshin 桜井勝之進 et al, eds., Nihon shintōron 日本神道論, Tokyo: Gakuseisha, 1999, p. 13.

20 For an analysis of the transformation of Seimei from a historical to a mythological figure and of the current evolution of his image, see Saitō Hideki, Abe no seimei-inyō no tassha nari 安倍晴一陰陽の達者なり [Abe no Seimei: Yin-yang Proficiency], Kyoto: Mineruba shobō, 2004.

21 Of the comics the most popular has undoubtedly been Onmyōji 陰陽師 (Tokyo: Hakusensha), designed by Okano Reiko 岡野玲子 and published in 11 volumes between 1994 and 2001.

Culture and Cosmos 
precincts, impressed on the roof tiles, on the banner and votive lanterns, and on the votive tablets (ema 絵馬) that shrine-goers inscribe with their prayers to the gods (Figs. 15a-b). Posters on the wall of the shrine offices advertise the new DVD of one of the films on Abe no Semei (Fig. 16). This shrine, too, offers a variety of cosmological amulets for sale, while another shop adjacent to it has exploited the current yin-yang trend by producing all sorts of goods, from T-shirts to pens and cosmetic paper sheets, marked with the Seimei star and other yin-yang symbols ${ }^{22}$ (Fig. $17 \mathrm{a}-\mathrm{b})$

This is not the forum to analyse in detail the contemporary status of astrology. It should be noted, however, that the Seimei Shrine is one example of the response of old establishments to the growing interest of the general public in the stars and astral practices. It is also evidence of the extent to which astrology has been a tangible and public phenomenon throughout Japanese history. Today in hyper-modern Tokyo there are divination corners in department stores and in front of station entrances, while consultation on birth stars and other celestial influences is offered not only at such shrines as the one devoted to Seimei, but also in new religion movements. Agonshū, for instance, one of the most technological of these groups, hosts a 'Star Festival' (hoshi matsuri 星祭り) on February 11 in the hills of Yamashina, eastern Kyoto. At this time large covered stalls are sets up in the compounds of the festival site, where qualified members offer their services in charting one's destiny in the year's movements of stars and planets. ${ }^{23}$

\section{Charting ritual modalities}

The cultic sites examined above help identify the coordinates of the development of the worship of the stars in Japan, and offer a few case studies of the patterns that have shaped this development, as well as analytical categories that may help in understanding Japanese religious astrology. Three major issues emerge: the diversity of agents and sponsors who promoted this cultic development in each period of

22 This shop originally manufactured textiles, as do other small businesses in the Nishijin area of Kyoto, where the Seimei Shrine is located. It started producing T-shirts and fabrics with yin-yang marks, eventually expanding to sell other goods, because of the demand that came especially from young visitors to the shrine. Personal conversation with the owner of the shop, April 2004.

23 Based on fieldwork conducted in February 2003. I am grateful to Yumiko and Paul Mitchell of the Agonshū Centre in London for guiding me through the site.

Culture and Cosmos 
14 The Worship of Celestial Bodies in Japan

Japanese history; the application of the knowledge of stars to different levels of the public and private realms; and the ritual interpretation of deified celestial bodies with its changing iconography, liturgical practices and legitimizing function.

\section{Origins and performers}

The convergence of religious traditions of different origins constitutes a major characteristic of belief and religious practice in Japan, and the way of dealing with stellar entities followed the same pattern. All religious institutions were involved in forms of astral worship, but Yin-yang thought and Buddhism were arguably the two main agents in the formulation of the Japanese perspective on celestial bodies. By the medieval period uranomancy, the science of divination based on stars, was called tenmondō 天文道 or sukuyōdō 宿曜道, according to its origins. The first term indicated a Yin-yang (Jap. Onmyōdō 陰陽道) type of divination, which derived from that performed in China for state purposes; the second term referred to a portion of Esoteric Buddhism, which was brought to Japan by the monks who went to China to study Buddhism, and initially gained popularity among the aristocratic elite. ${ }^{24}$

It should be noted that the Chinese Buddhist canon included several books that incorporated Indo-Iranian astrology, which had found its way to East Asia through the channel of Buddhism and enjoyed much popularity in China under the Tang dynasty (618-907). ${ }^{25}$ Indian knowledge of the stars greatly influenced the evolution of Chinese divinatory techniques and introduced new notions in the Chinese understanding of celestial bodies, which were to become fundamental in the Japanese system. For example, to the fundamental astral bodies, sun, moon and the five visible planets, it added two imaginary bodies that personified the nodes of the moon's orbit, and were associated with eclipses. Together these bodies would be known as the 'Nine Numinaries' (kuyō 九翟) and would become a basic element in the

24 Nagai Susumu 永井晋, 'Tenmondō to sukuyōdō 天文道と宿曜道, ' in Sano Kenji, ed. Hoshi no shinkō: Myōken, Kokūzō 星の信仰：妙見・虚空蔵 [The Worship of Stars: Myōken and Kokūzō], Tokyo: Hokushindō, 1994, pp. 121-33.

25 For an analysis in English of one such text, see Angela Howard, 'Planet Worship: Some Evidence, Mainly Textual, in Chinese Esoteric Buddhism,' Asiatische Studien 37, 2 (1983). A similar document, of Japanese provenance, is translated in Matsumoto's contribution to this volume.

Culture and Cosmos 
anthropomorphic representation of the astral universe, ultimately included as deities in the mandalic charts of the sky that were first devised in China and developed more remarkably in Japan. The multilanguage titles that were used for these deities in Sino-Japanese Buddhist texts also suggest the introduction of a 'planetary week' in China and then in Japan, which was derived from Iranian sources ${ }^{26}-$ a fascinating aspect of the circulation of what we can call 'uranosophia' between the Western and Eastern areas of the Eurasian continent.

\section{Power over the skies: political legitimacy and propitiation}

In Japan, as in China, the science of the stars was thus integrated into a complex system of belief that included lucky and unlucky days, geomantic positions, and zodiacal animals. The two branches of divinatory expertise mentioned above came to control separate areas of pre-modern life. Tenmondo took as its object the destiny of the ruler and phenomena of State relevance, such as wars and epidemics; accordingly, this type of divination was employed in the implementation of power strategies at state level, both by the court and the shogunate. On the other hand, sukuyōdo was concerned with individual fate, of courtiers and officials to begin with, and used horoscopes to tell fortunes. In reality, however, these two types of expertise on the stars were complementary and both influenced Japanese society to different degrees in differing historical periods. It may be argued, though, that to the extent that Tantric Buddhism incorporated part of the expertise of the Yin-yang specialists, it dominated the religious handling of the stars, at least since the Heian period.

Political control over the heavens, symbolically and pragmatically, was a crucial aspect of interest in stars and planets in pre-modern societies. It was explicated first of all as control over time, as is evident in the production of the calendar, which was originally the prerogative of the emperor and embodied the power of the state. Japanese calendars were compiled by tenmondo specialists, and were based, until the seventeenth century, on a Chinese model brought to Japan in 862. Throughout this time calendars were made almost exclusively for the court and aristocracy but, from the Tokugawa period, they became a practical tool

26 See É. Chavannes, 'Une traité manichéen retrouvé en Chine,' Journal Asiatique 11,1 (1913), pp. 159-178, and Yano Michio, 'The Hsiu-yao ching and its Sanskrit Sources,' in Swarup, Bag and Shukla, eds. History of Oriental Astronomy, Cambridge: Cambridge University Press, 1987, pp. 125-34.

Culture and Cosmos 
in the life of the populace. Various forms of calendar existed, and they served as textbooks on time by indicating the seasons and the length of the months, a type of knowledge that was indispensable to farmers and merchants, and by prescribing what to do or not do on specific days in relation to the movement of a planet. $^{27}$ Simplified versions of these traditional calendars are still compiled and sold for a few hundred yen at temples and shrines, especially around the end of the year, and are even available for customers to take away in some commercial establishments in Kyoto (Fig.18).

Control over the heavens also operated in a second mode, that is, control over celestial and terrestrial space, as suggested in the cult of Daishōgun described above. This, too, was originally regarded as part of the expertise of Yin-yang specialists in the service of the aristocracy. In the countryside, however, rituals that focused on precautions towards baleful directions were often offered by other religious specialists, including Buddhist monks and shugenja 修験者. The mantic art related to the stars in sukuyōdo, too, was conceived as knowledge over planetary positions in time - a science that allowed control of matters of life and death.

\section{Ritual appropriations}

Astrology combined with Tantric Buddhism to devise liturgies and offerings that had the power to weaken negative astral influences, and to produce apotropaic and exorcistic talismans that facilitated more harmonic relationships between the heavens and one's daily conduct. The ritual appropriation of celestial bodies took in Japan a great variety of forms and was developed in changing modalities. I shall outline a number of features here.

The first characteristic that emerges from the analysis of ritual material related to stars is a typological differentiation among stellar deities, whereby the same celestial body took a number of names, although its function remained similar. A representative example is the Polar Star. In its Buddhist guise it was venerated as Sonshōo 尊星王 at court and in the area of the capital, and as Myōken in the Eastern provinces and among the samurai lineages. ${ }^{28}$ In Onmyōdō circles it was worshipped as

27 An overview in English of the different types of calendar that were produced through history in Japan may be found on the website of the Diet Library, http://www.ndl.go.jp/koyomi/e. 
Chintaku reifujin 鎮宅霊符神, and sometimes identified with Taizan fukun 泰山府君, the 'Great One' (Taiyi, Jap. Taiichi 太一) of Taoist tradition. ${ }^{29}$ Yet these distinctions were more fluid than they appear at first, and changes occurred not only over time but also due to the social background of the worshippers, as we have seen with the transformation of the Pole Star into a popular cult in the Edo period. The Pole Star is also a case in point that emphasizes the versatility of the ritual significance of astral deities: on one level it was used as an imperial symbol; on another level it was appropriated by Tantric Buddhism for exorcistic rituals; and on yet another level it was popularized in the devotional forms that continue today. Insofar as icons are an indispensable element of ritual action, the deification of stars triggered the development of a complex iconography, which depicted celestial bodies as individual deities (Daishōgun or Kōkuzō, for instance) or as groups of deities (the Big Dipper or the Nine Luminaries), while the most comprehensive attempt to represent the heavens anthropomorphically was contained in the star mandalas. Each type of icon reveals the function it fulfilled in the ritual context. Small-size wooden statues testify to a more personal worship, at home or in small dedicated halls. Examples are the images of Myōken that may be found today on the side altars of Nichiren temples, often donated by pious believers. In the Tokugawa period, the image enshrined in the Myōken Hall at Sanpōji (Fig. 11), according to the priest in charge, used to be brought down from the hills of West Kyoto, where the temple is located, to various houses in the city, for the convenience of worshippers who found it difficult to reach the temple. The elaborate mandalas painted in silk, on the other hand, were produced for wealthy patrons or major temples of the Tantric schools, to be used in grand secret rituals (hiho 秘法).

In the mandalic diagrams of the sky the major planets, zodiac signs, lunar mansions and other bodies were arranged in their deified forms, not

28 On the worship of Myōken in various provincial clans, see Kanezashi, op. cit., pp. 227-260.

29 In turn, Taizan fukun was also venerated in Buddhist mode as Sekizan myōjin 赤山明神, who became one of the tutelary deities of the Tendai school of Buddhism and had a major centre of worship in the north-east area of Kyoto, at the foot of Mt Hiei. This is an astral site still active today. For an overview of the identity of the Pole Star as Chintaku reifujin and Taizan fukun, an important aspect which could not be explored within the limits of this introduction, see Kanezashi, op.cit., pp. 169-80. 
18 The Worship of Celestial Bodies in Japan

necessarily reproducing their actual reciprocal positions but rather charting a hierarchical composition according to their ritual importance. Other patterns were created to represent the stars during the liturgical performance itself. This topic has not received much scholarly attention, but it is well documented in medieval sources. Let us take the Buddhist rituals to the Big Dipper as an example. Of the three different types that existed, the so-called 'great ritual' was performed at seven altars, consisting of a platform for the fire ritual (gomadan 護摩壇) placed in the middle of the hall and three smaller platforms at each side. Another type, known as the 'night ritual' because its performance was carried out through the night, was originally celebrated on the seventh day of the month, and reiterated star patterns in the arrangement of the various implements on the altar. A simple drawing of the goma platform set for a candle service (rōsokuku 蠟燭供) to the stars is included in an unpublished manuscript called Hokuto kuho 北斗供法 [Ritual for the Worship of the Big Dipper], transmitted within the Tōji 東寺 lineage of Esoteric Buddhism, and now among the holdings of the Fujii Eikan Archives in Kyoto ${ }^{30}$ (Fig. 19a). The offerings to the seven stars of the Big Dipper are disposed around the fire-burning plate, while at the corners, clockwise from the top right, are allocated the offerings for the personal star (honmyōshō 本命星), the birth mansion (seigatsugu 生月宮), the personal constellation (honmyōshuku 本命宿) and the star of the year (tōnen zokushō 当年属星). ${ }^{31}$ The personal stars were those related to the person who sponsored the liturgy. Similar diagrams may be found among

30 According to the colophon, this document was transmitted and copied in 1278. The original may have been compiled by Myōe (1173-1232), since the document is presented as a transmission of Jümujin-in shōnin. The diagram is drawn on the reverse side of the ritual procedures. I am grateful to the Art Research Centre of Ritsumeikan University, Kyoto, where the Fujii collection is kept, for allowing me to examine the document and for providing the photos.

31 The term seigatsug $\bar{u}$ used in this text indicates, I believe, the astral body otherwise known as honmyog $\bar{u}$, that is, the constellation (mansion) where the sun resides in the month in which an individual is born. Medieval transmissions present different explanations as to whether this referred to the month or the day of birth. For details see Morita Ryūsen 森田龍僊, Mikkyō senseihō 密教占星法 [Astrological Rituals in Tantric Buddhism], Kyoto: Rinsen shoten, 1944, vol. 1, pp. 291-95.

Culture and Cosmos 
the medieval documents collected at Kanazawa Library. A more elaborate drawing of a goma platform shows eight offering trays, one for each of the seven stars of the Big Dipper and one for Myōken. This is placed in the middle of the altar and counted as the first star. The offerings drawn on the trays are presumably rice: the annotation on the margin of the diagram, in fact, prescribes a candle service at the 'beginning of the night' (that is, around 8:00 pm), and offerings of cooked rice ( kayu 弹) to each of the stars to be made later in the night. ${ }^{32}$ A second drawing, also in the collection of Kanazawa bunko, shows the platform for the performance of yet another ritual, dedicated to the socalled Seven-star Nyorin Kannon. Here seven candles representing the Big Dipper are placed in the centre, while offerings to the Nine Luminaries, the Twelve Mansions, the Twenty-eight Mansions and the Seven Astral Bodies are placed at the four corners of the altar, in clockwise order. ${ }^{33}$ During this ritual a painting of the bodhisattva Nyorin Kannon with the seven stars of the Big Dipper depicted around her was hung behind the altar, in this way embodying the presence of the astral deities during the performance. ${ }^{34}$ These three documents thus present a sample of the variety of performative possibilities that were created for

32 Hokuto goma shiki [Private Instructions on a goma for the Big Dipper], owned by Tan'ei 湛睿 (1271-1346), third abbot of Shōmyōji. A photograph of the drawing is included in Kanagawa kenritsu Kanazawa bunko 神奈川県立金沢文庫, Chūsei no uranai 中世の占い [Medieval Divination], Special exhibition, Kanazaka bunko: 1989, p. 45, exhibit no. 32. The three personal stars and the year star are placed in the corners, albeit in a mirror-like position with respect to that they occupy in the Fujii Eikan manuscript. The diagram also indicates the offerings of flowers, banners and other ritual implements.

33 Shichisei nyoirin danyō 七星如意輪壇様, Kamakura period (13th c.). A photograph of one of the drawings in this document is included in Kamakura jidai no mikkyō gishiki 鎌倉時代の密教儀式, (Special exhibition) Kanazawa bunko: 1983, p. 34, exhibit no. 59.

34 An example of such paintings is included in the article by Tsuda in this volume (Fig. 11). For a short description of images of Nyorin Kannon and the Big Dipper, see Takeda Kazuaki 武田和昭, Hoshi mandara no kenky $\bar{u}$ 星曼茶羅の研究 [Studies on Star Mandalas], Kyoto: Hōzōkan, 1995, p. 25-7. Stars were also added to the iconography of other deities, and often served to emphasize the unity of earth and heaven and to increase the efficacy of the ritual.

Culture and Cosmos 
20 The Worship of Celestial Bodies in Japan

worshipping the stars in the medieval period, across the Tantric tradition - and, to a certain extent, are still generated today in Japan's multifaceted religious landscape. ${ }^{35}$

The purpose of the ritual performed to the Big Dipper was to increase one's lifespan: according to the canonical text that served as a model for the Japanese versions, a text supposed to have been translated in China by the Indian Tantric master Amogavajra, those who venerated the stars in conformity with the rules of this ritual held back death and returned to life. ${ }^{36}$ The Japanese ritual manuals not only expanded on this function, or offered other technical details such as the specific food offerings for each star according to the correspondent sign of the Zodiac. They further contained general information on the stars to which the ritual was dedicated, which may have been of use to the celebrant to fit the specific liturgical occasion of which he was the actor in the larger context of the contemporary dealing with the star. On the reverse side of the Fujii Eikan manuscript mentioned above, for instance, we also find the diagrams of two different patterns in which the Pole Star was represented: the seven stars of the Big Dipper; and the so-called 'five stars of the Pole' (hokkyoku gosei 北極五星), that is, the Pole Star and the four auxiliary stars that surround it (shibosei 四輔星). A later hand annotated this section of the scroll, adding the alternative names by which each of the stars of the Big Dipper was also known (Fig. 19b).

A final note should be reserved for the invocations to celestial bodies: as deities of the Tantric Buddhist world, stars and planets were also supplied with mantras. These mantras became the central ritual segment of an entire practice, as in the case of the meditation on the morning star discussed earlier; or they were inserted into more sophisticated liturgical forms according to standard esoteric rituals. Mantric formulas were also used in simpler divinatory practices centred on the stars. It may be suggested that the specific cults of personal stars and protective honzon 本尊 corresponding to Zodiac signs, which are still practised today in Japan, all resulted from a distillation and simplification of the complex Tantric liturgies. This is another subject that needs to be addressed in a further study.

35 For photographs of one version of the ritual to the Big Dipper performed currently, see the article by Sekimori in this volume.

36 Hokuto shichishō goma hiyō giki 北斗七星護摩秘要儀軌, T. 21, no. 1306.

Culture and Cosmos 


\section{The Essays in This Volume}

The essays included in this volume explore features of the worship of stars in different periods and contexts of Japanese history. They analyse the cultural background in which cultic customs devoted to celestial bodies developed under the influence of continental knowledge and beyond it, and discuss some of the issues outlined above in this introduction. The essays were papers delivered at the workshop The Worship of Stars in Japanese Religious Practice, organized in September 2004 by the SOAS Centre for the Study of Japanese Religions, with the exception of the article by Ikuyo Matsumoto, which was especially written for the issue of this journal in order to complement the material presented at the workshop. While the study of astrology and its religious aspects in China has long since been the object of scholarly attention, hardly any material on this subject in Japan is available in Western languages. Even in Japanese only a few studies exist, mostly on a set number of topics, as the basic bibliographic list included at the end of this introduction illustrates. The CSJR workshop was a first attempt to redress this situation and draw a larger picture of the relevant material and possible methodological approaches, harnnessing the knowledge of specialists from different disciplines that ranged from political and social history to art and history of religion. Only a handful of themes could be covered in the limited space of the workshop, leaving important topics, such as the beliefs and practices directed to sun and moon, and the influence of Taoist deities and ritual interpretation, to a future occasion. The papers, however, addressed a number of common concerns and shared some material, allowing a rounded analysis of the topics.

The activities of onmyoji, the specialists of the mantic science par excellence, are the subject of Hayashi Makoto's essay. Hayashi gives an historical outline of how onmyōji were engaged by the political leaders in each period of ancient and early modern history, while in the medieval period expertise on the stars was mostly in the hands of Buddhist priests, who were institutionally intertwined with the agencies of political power. One of the major tasks of the astronomer-astrologer at the service of the State was the making of the calendar, but this science developed in Japan with a dynamics that differed from that on the continent.

Calendars had also an impact on society at large, as John Breen's contribution demonstrates. His paper discusses the structure of the printed almanacs that spread around the country in the Tokugawa period, and points out how the fear of disturbing, through a lack of knowledge or 
wisdom, the cosmic order embodied by stellar deities, persisted well into the nineteenth century, in spite of the introduction of Western science.

Chinese cosmological patterns shaped Japanese practices also in the process of establishment of the most 'indigenous' cultic sites. Mark Teeuwen's essay focuses on Ise, the shrine complex connected to the Japanese royal dynasty, and discusses the extent to which the shrine structure drew from Chinese astral symbolism. According to some interpretations, this shrine was originally centred on the cult of the Pole Star, which embodied the emperor in China, a connection which seems never to have wavered throughout Japanese history, even after the worship of the sun in the form of Amaterasu, the Sun goddess and imperial ancestor, was established at this site.

The Chinese legacy is also evident in the Buddhist practices of the stars. To introduce this aspect, Lilla Russell-Smith explores texts and imagery which were produced in China and which related to celestial bodies. She elucidates how in Buddhist sutras the planets are often described as paying homage to the Buddha, and how many paintings represented them in human form, surrounding a central Buddha. Using Dunhuang material, she explains that this arrangement came to symbolise the Buddha's rule over time and space, and his control over calamities. In turn, established connections between the position of the sun and the planets, and the status of the earthly rulers, served the legitimizing agendas of the patrons of this worship.

While Russell-Smith focuses on the artistic development of the worship of stars, the two medieval documents presented by Ikuyo Matsumoto provide examples of the extensive astrological literature, consisting of ritual instructions and talismanic verses, which was first compiled in China under the influence of Central Asian astrology, and then reproduced and re-used in the Japanese Buddhist contexts. The first document is a short ritual manual that illustrates the liturgical procedures and recitations to be followed in the veneration of personal stars. The ritual follows the common structure of a Tantric liturgy to individual deities, but the object of veneration comprises several stellar deities, such as the constellations, the lunar mansions and the Zodiac. The second document is a concrete example of uranomancy, describing how to foretell the character of people based on the influence of the planets, as well as the unlucky or lucky events that befall people whose stars enter within the sphere of action of certain luminaries. This document, too, prescribes ritual actions that originated in Tantric Buddhism: an example is the recitation of mantras to remedy calamities brought about by the 
movements of celestial bodies. Several Chinese works of this genre, and often of more complex form, were popular until the late medieval period in Japan, attesting to the continuous relevance of continental models.

The predominant role that the Pole Star and the Big Dipper played in astrological representations and liturgies is the subject of the following three papers. Tsuda Tetsuei presents a fascinating excursus of the particular iconography of the Pole Star that was developed in the context of Japanese Tantric Buddhism, pointing out the original features with respect to continental models. His essay addresses political issues that surround these images, and demonstrates how ritual iconography was produced, used and reinvented, not only to provide diversified liturgies for an aristocratic class in need of religious support, but also to legitimise different Buddhist schools.

Meri Arichi presents another case study of medieval interpretations of the Ursa major. She examines the belief in the Sannō kami developed at Hie Shrine, on the shore of the lake Biwa, north-east of the capital Kyoto. At this cultic centre, closely related to political power blocks in the capital, the seven stars of the constellation of the Big Dipper were associated with the seven principal shrines of the Hiei complex, establishing a perfect symmetry between astral position in the heavens and human geography on earth. This essay also examines the iconographic transposition of these beliefs into the mandalas representing the Sannō kami.

The last essay illustrates a contemporary liturgy devoted to the Pole Star. Gaynor Sekimori discusses the presence of star shrines in Nikkō, an ancient centre of mountain asceticism (shugendō), which today is known only for its connection to shogunal politics. She analyses the historical importance of the halls for star worship in the area, and presents an anthropological account of a traditional Tantric star ritual that has been recently revived by new shugendo groups. Mountain practitioners (shugenja) were another type of religious specialist who also contributed to the diffusion of astrologic knowledge at a local level, and this essay focuses on their indigenous practices and the role they played in the landscape of Japanese stellar cults.

These essays give an indication of major avenues of research in the field, as well as of the lacunae that need to be filled. I hope that they will serve to generate interest in a crucial aspect of Japanese religious practice and become an incentive to further, multi-disciplinary, research. 
24 The Worship of Celestial Bodies in Japan

Fig. 1 Map of Kyoto highlighting the grid of the old capital with the imperial palace at the upper centre and the mythical animals associated with the four directions depicted at the sides of the old city (North is at the top). The names in bold, marked by a torii or a Buddhist cross, mark temples and shrines that are today associated with protection from baleful influences.

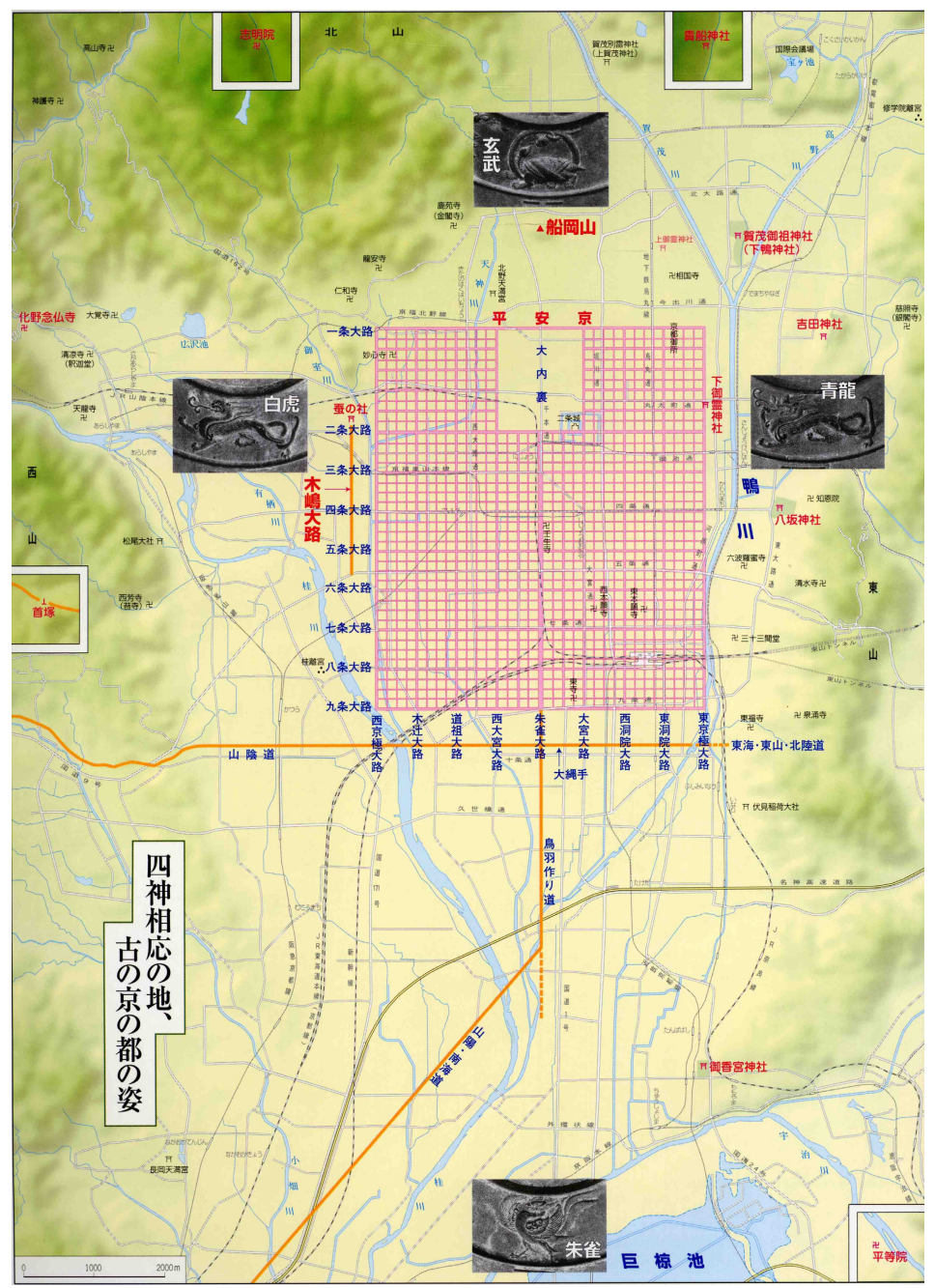

Culture and Cosmos 
Fig. 2a The torii at the entrance of Daishōgun Shrine, Kyoto. Next to the right pillar, a bamboo with paper wishes hanging from its branches marks the Tanabata festival.

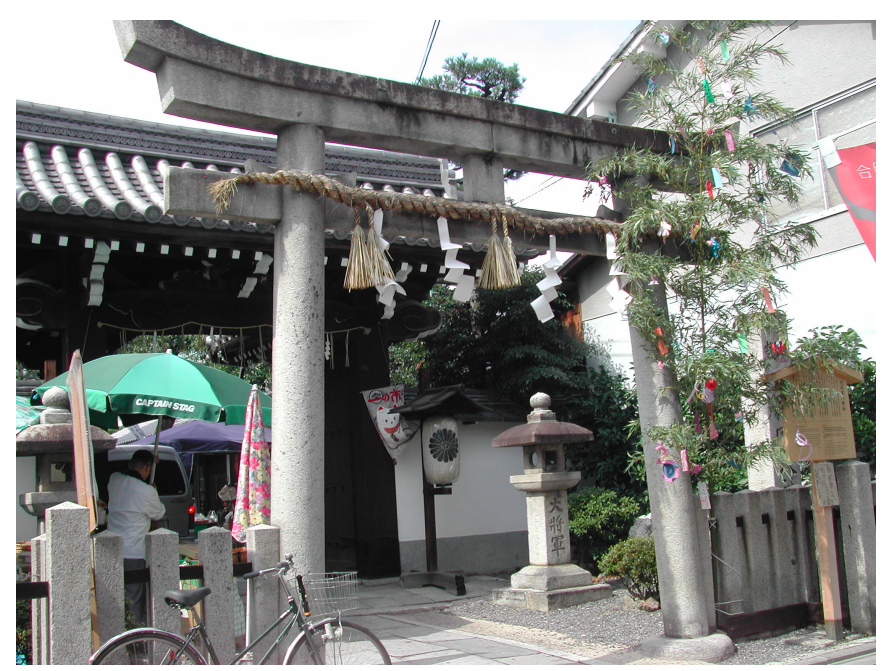

Fig. 2b Inner precincts of Daishōgun Shrine. A star monument stands in front of the main worshipping hall. The octagonal base that supports the star inscribes the names of the eight directions in Chinese characters.

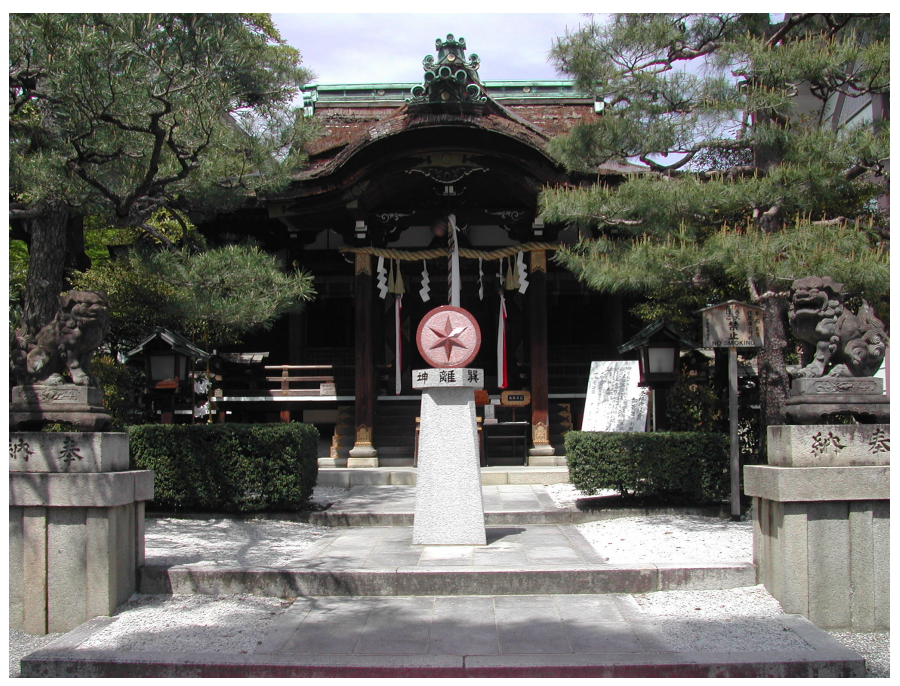

Culture and Cosmos 
26 The Worship of Celestial Bodies in Japan

Fig. 3 One of the statues of Daishōgun kept in the Treasure Hall of the Daishōgun Shrine. It shows the deity in the guise of a warrior, holding a sword and making the sword mudra with the left hand.

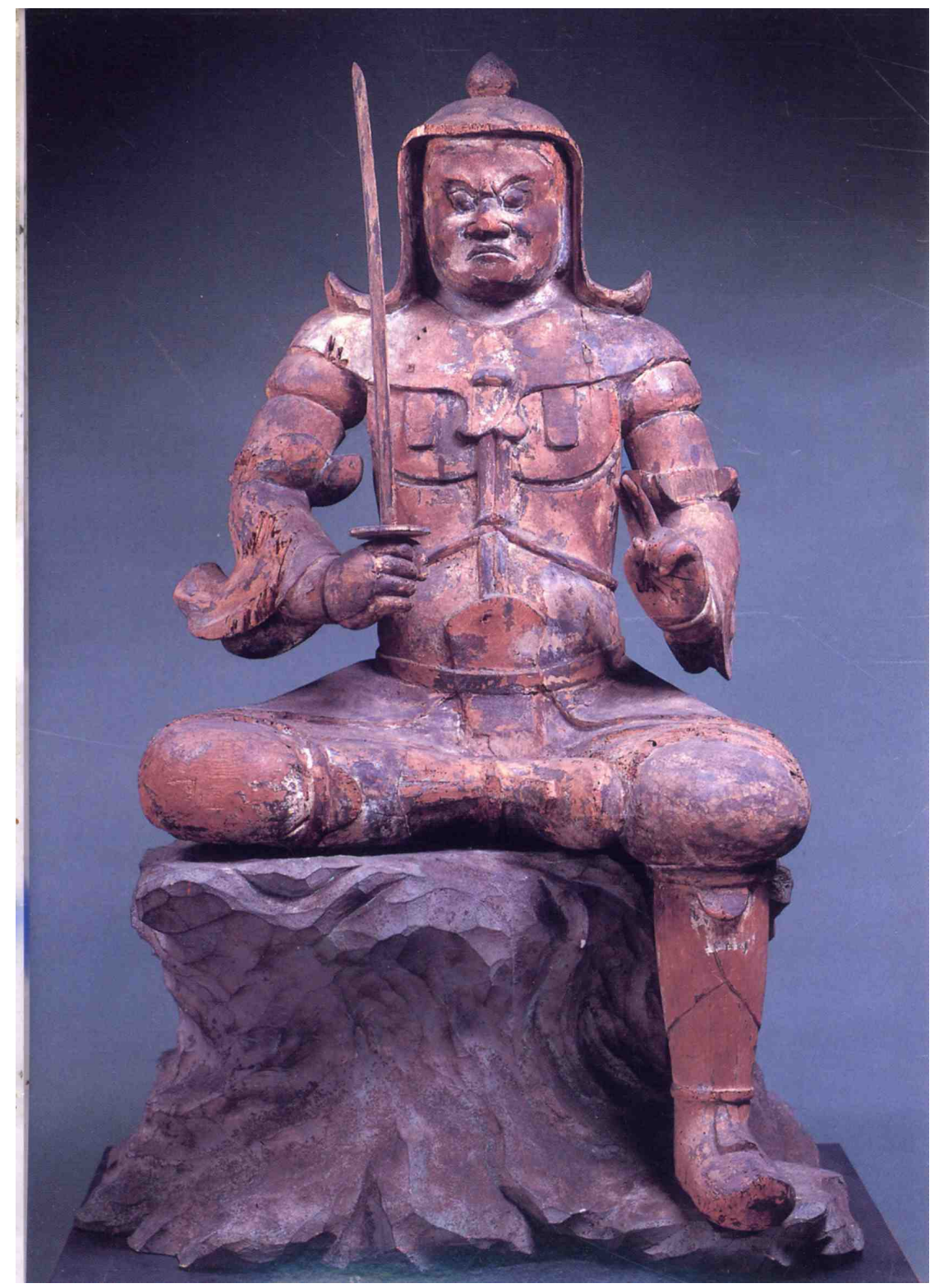

Culture and Cosmos 
Fig. 4a Astrological amulets (omamori) on sale at the Daishōgun Shrine. Some depict the directions with the associated colours. Others are decorated with the motif of the Big Dipper.

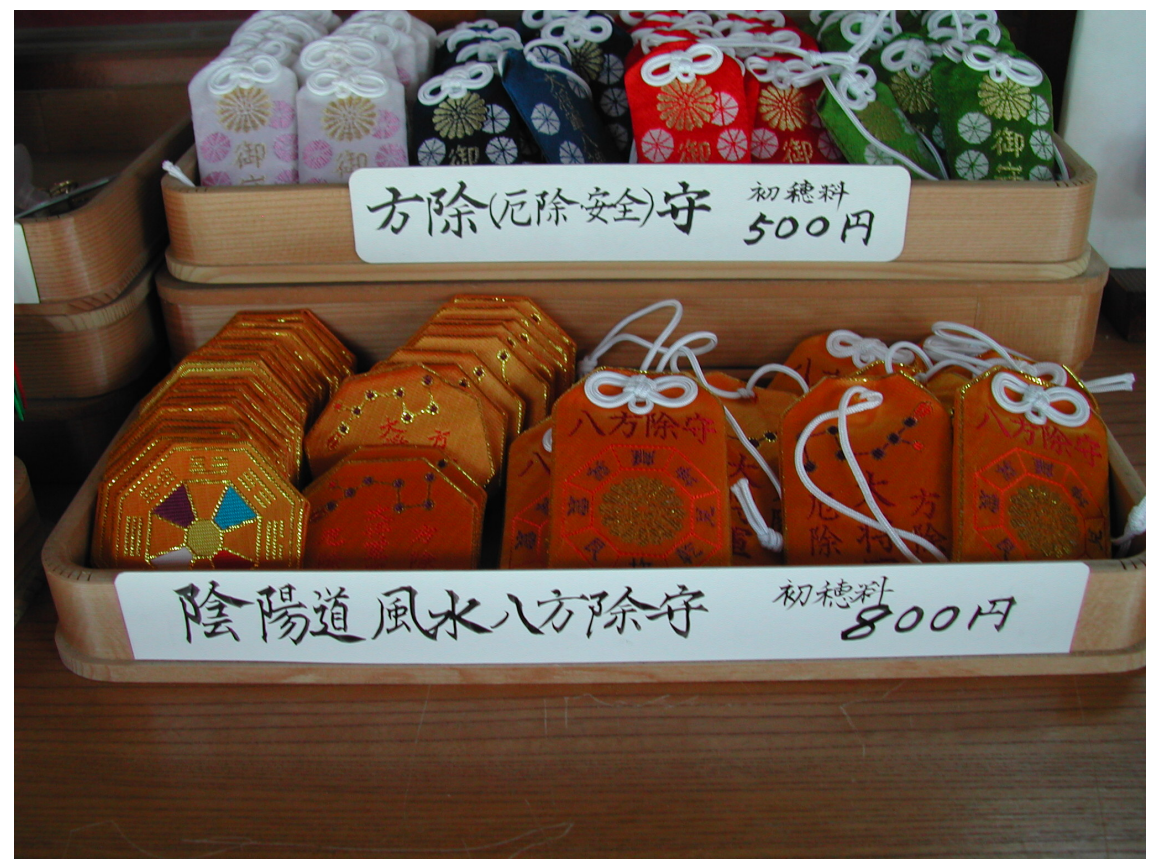

Culture and Cosmos 
28 The Worship of Celestial Bodies in Japan

Fig. 4b Details of a wooden amulet with diagrams of the eight directions, on sale at Daishōgun Shrine. On the front side the four cardinal points are indicated by the names of the heraldic animals (North, genbu, is at the bottom), and the intermediate directions by gates (North-east is the 'gates of demons').

Fig. 4c The reverse side of the amulet indicates the correspondences between the directions and the Zodiac signs.

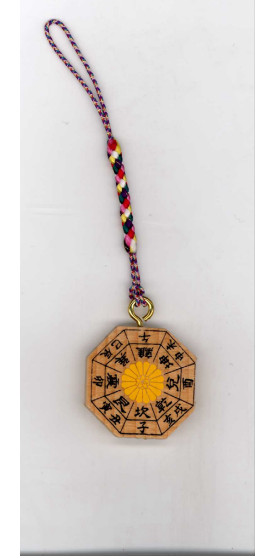

Culture and Cosmos 
Fig. 5 Paper talismans (ofuda) sold at Daishōgun Shrine. They inscribe, from left to right, the names of two ambulant planetary deities, Toshitokujin and Konjin, of the God of Kitchens, associated with earth, and of the God of Waters.

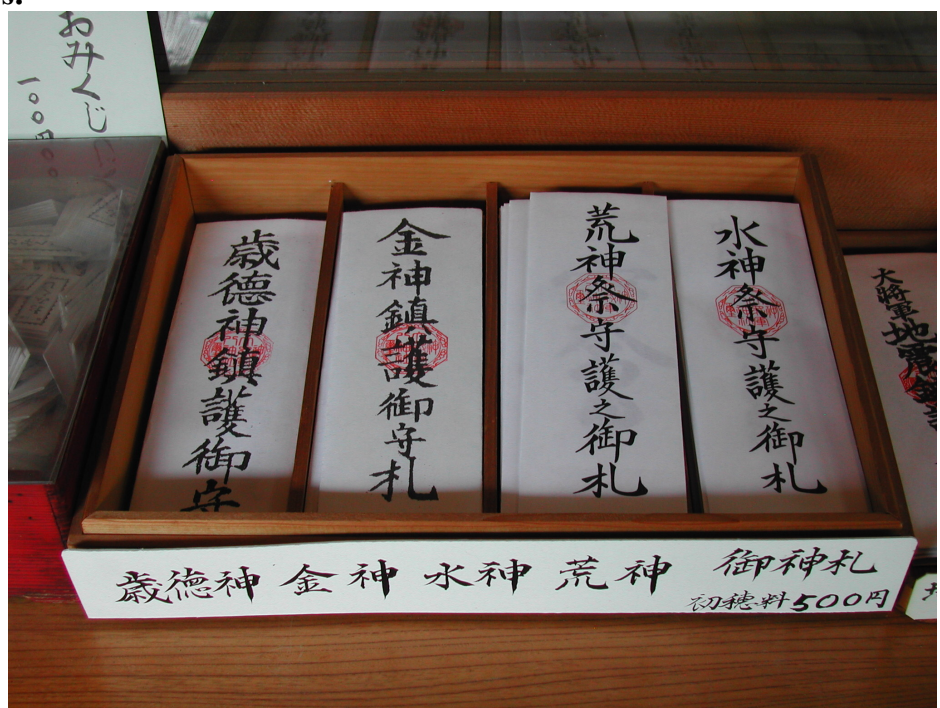

Fig. 6 A chart of the Big Dipper in the shape of a dragon. Treasure Hall of the Daishōgun Shrine.

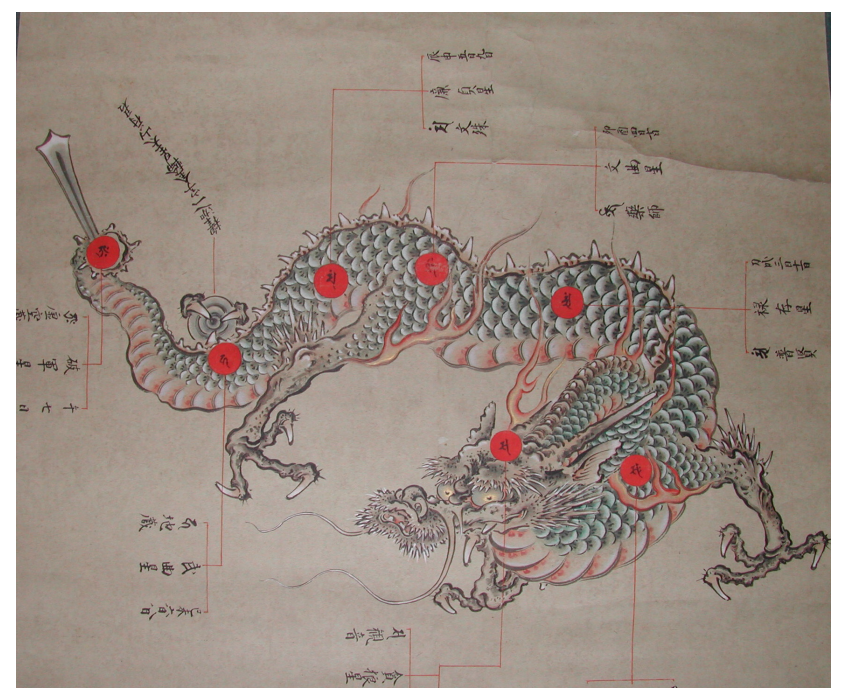

Culture and Cosmos 
30 The Worship of Celestial Bodies in Japan

Fig. 7 Hōrin ji, dedicated to the bodhisattva Kokūzō. Arashiyama, Kyoto.

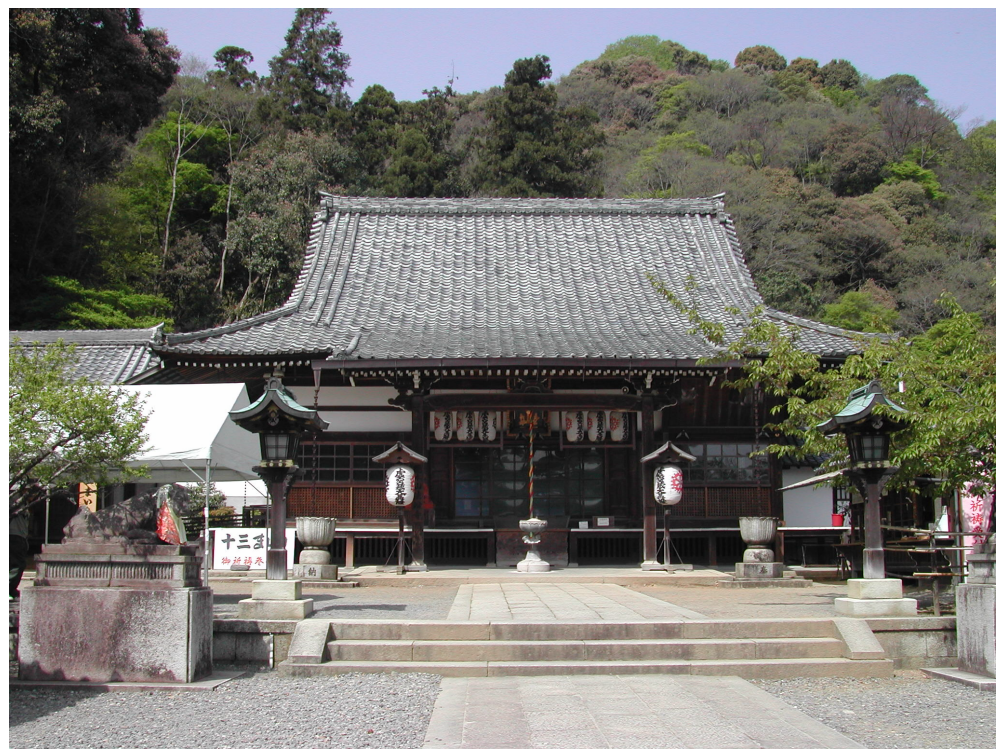

Fig. 8 Kiyosumidera, or Seichōji, in Chiba prefecture.

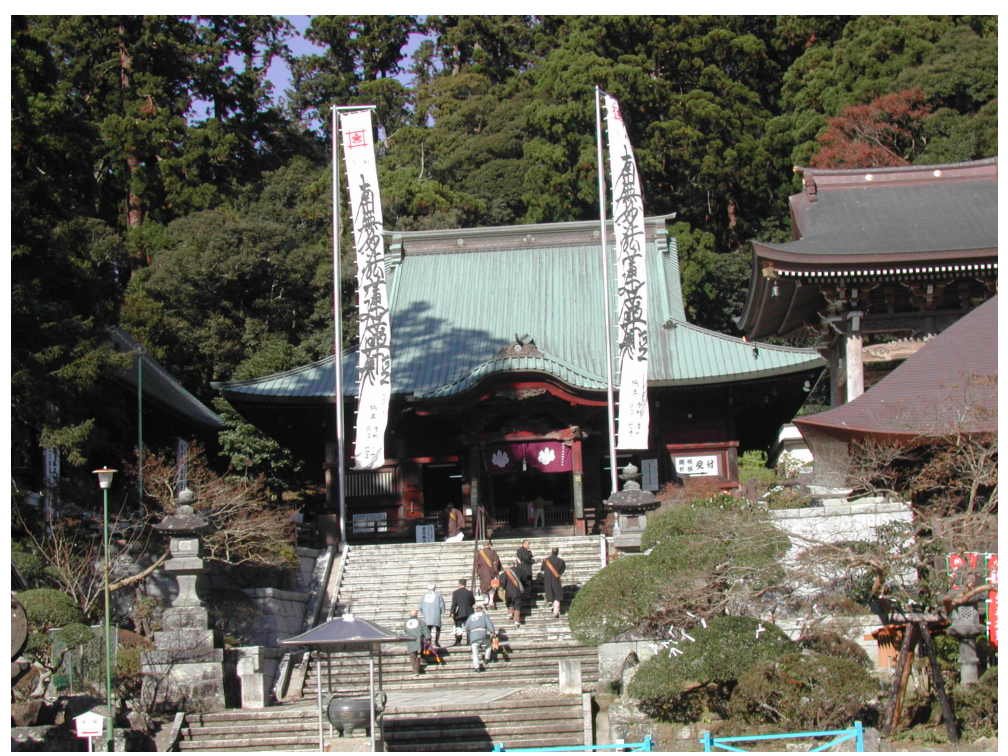

Culture and Cosmos 
Fig. 9 Shrine dedicated to the Pole Star in the precincts of a Nichiren temple. Honpōji, Kyoto. The inscription in golden characters says 'Pole Star Hall' (Hokushinden). On the altar is enshrined a small statue of the bodhisattva Myōken, together with two other protective deities of the Nichiren denomination.

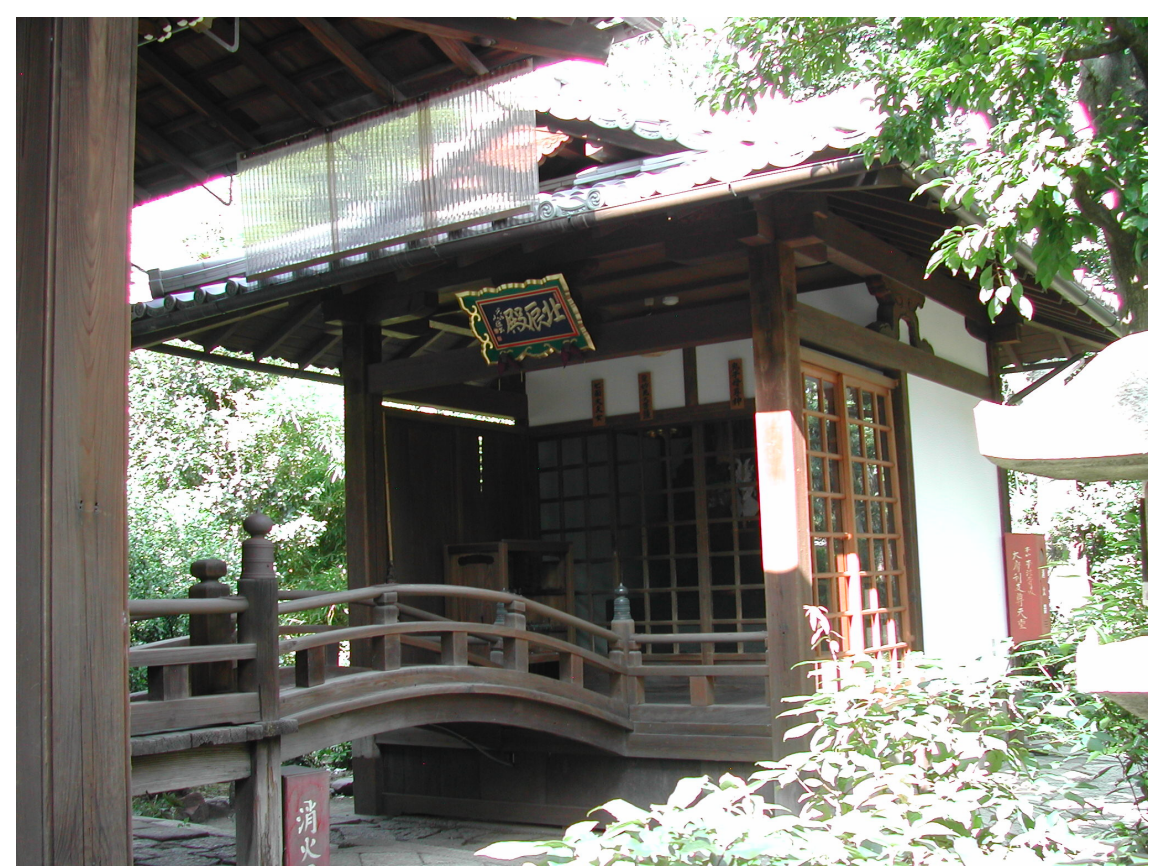


32 The Worship of Celestial Bodies in Japan

Fig. 10 A stele marking a cultic site devoted to the Pole Star as the 'All Wish Fulfilling Bodhisattva Myōken.' It stands today just outside the entrance of Sanbōji, a Nichiren temple in the hills of West Kyoto.

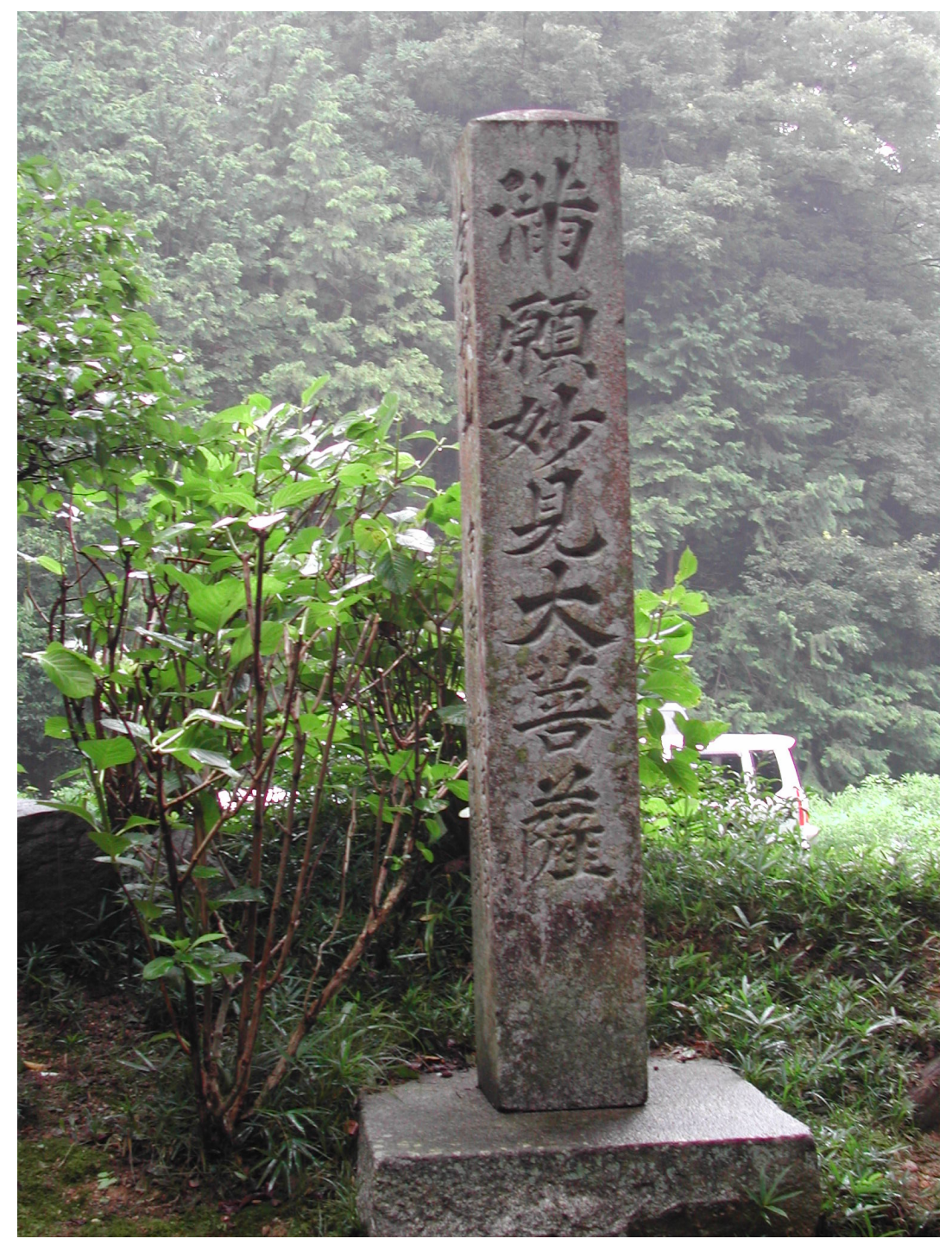

Culture and Cosmos 
Fig. 11 Detail of the inner shrine to Myōken at Sanbōji. The inscription in Chinese characters on the door gives the name of the shrine, Myōkengū, while the drapes are decorated with stars inscribing the Big Dipper. Inside, on the altar, is a small statue of Myōken standing on a rock (visible through the door grids).

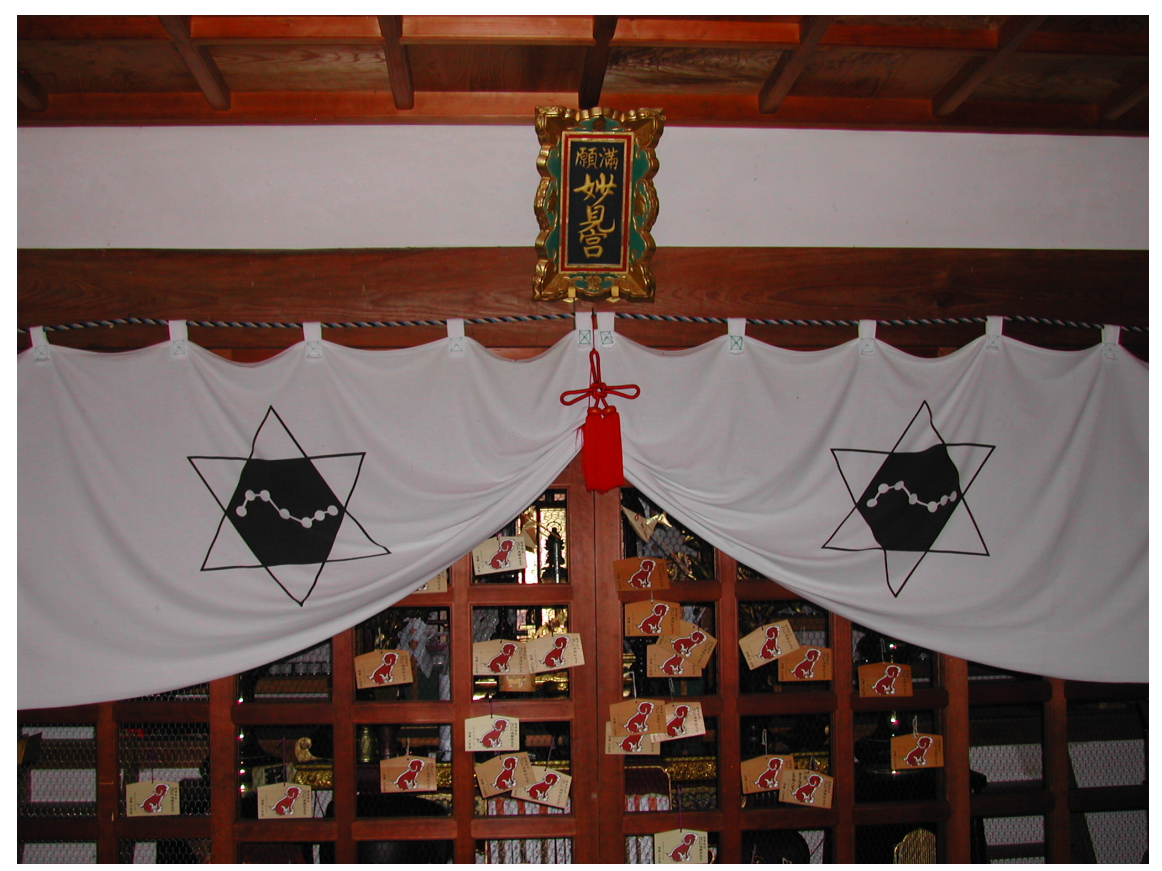


34 The Worship of Celestial Bodies in Japan

Fig. 12 Pamphlet advertising the pilgrimage to Myōken and the twelve Zodiac signs in Kyoto (rakuȳ̄ jūnishi Mȳ̄ken).

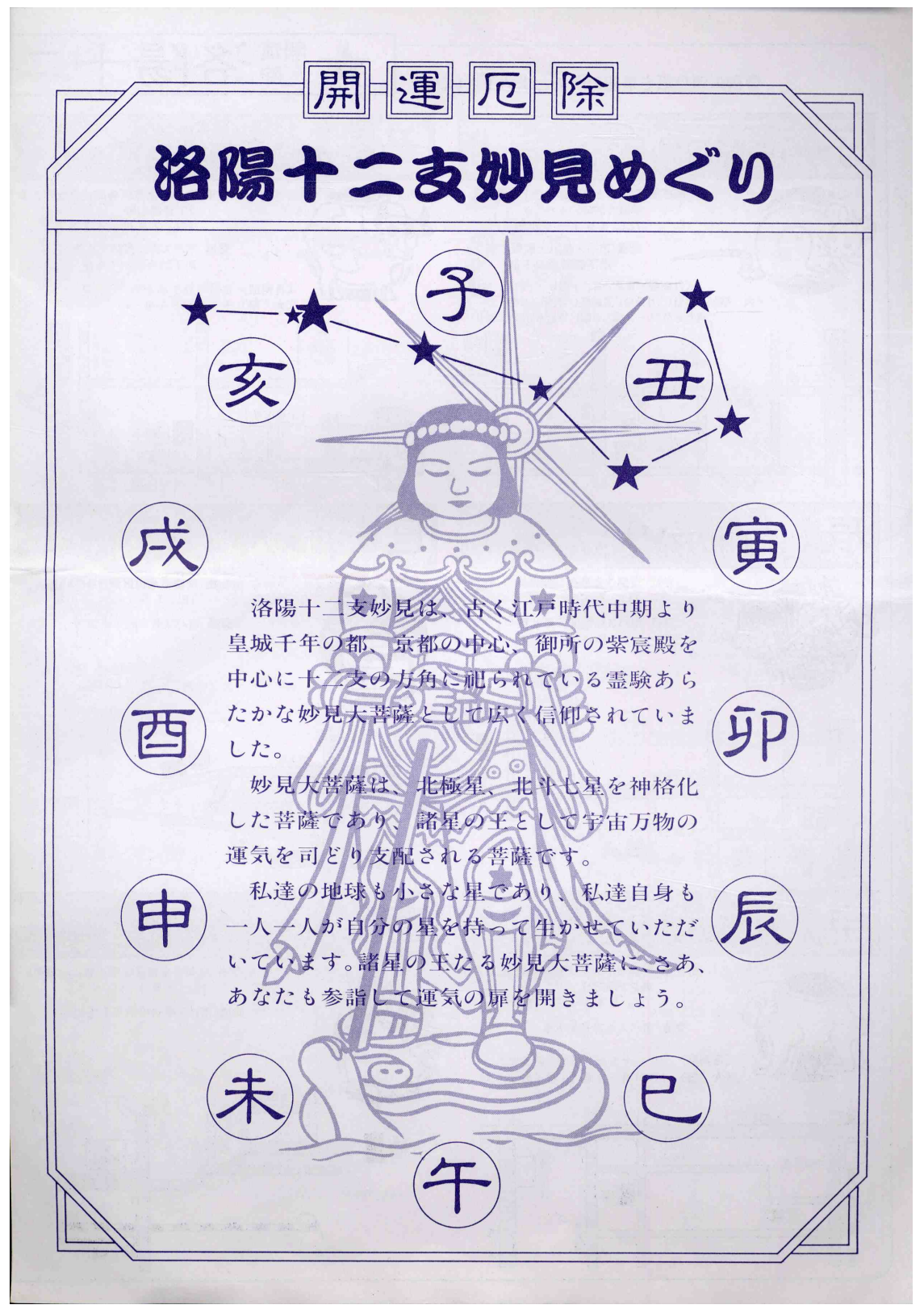

Culture and Cosmos 
Fig. 13 Hall dedicated to Myōken and the Zodiac sign of the Rabbit at Reikanji, an imperial convent in Shishigatani, Kyoto.

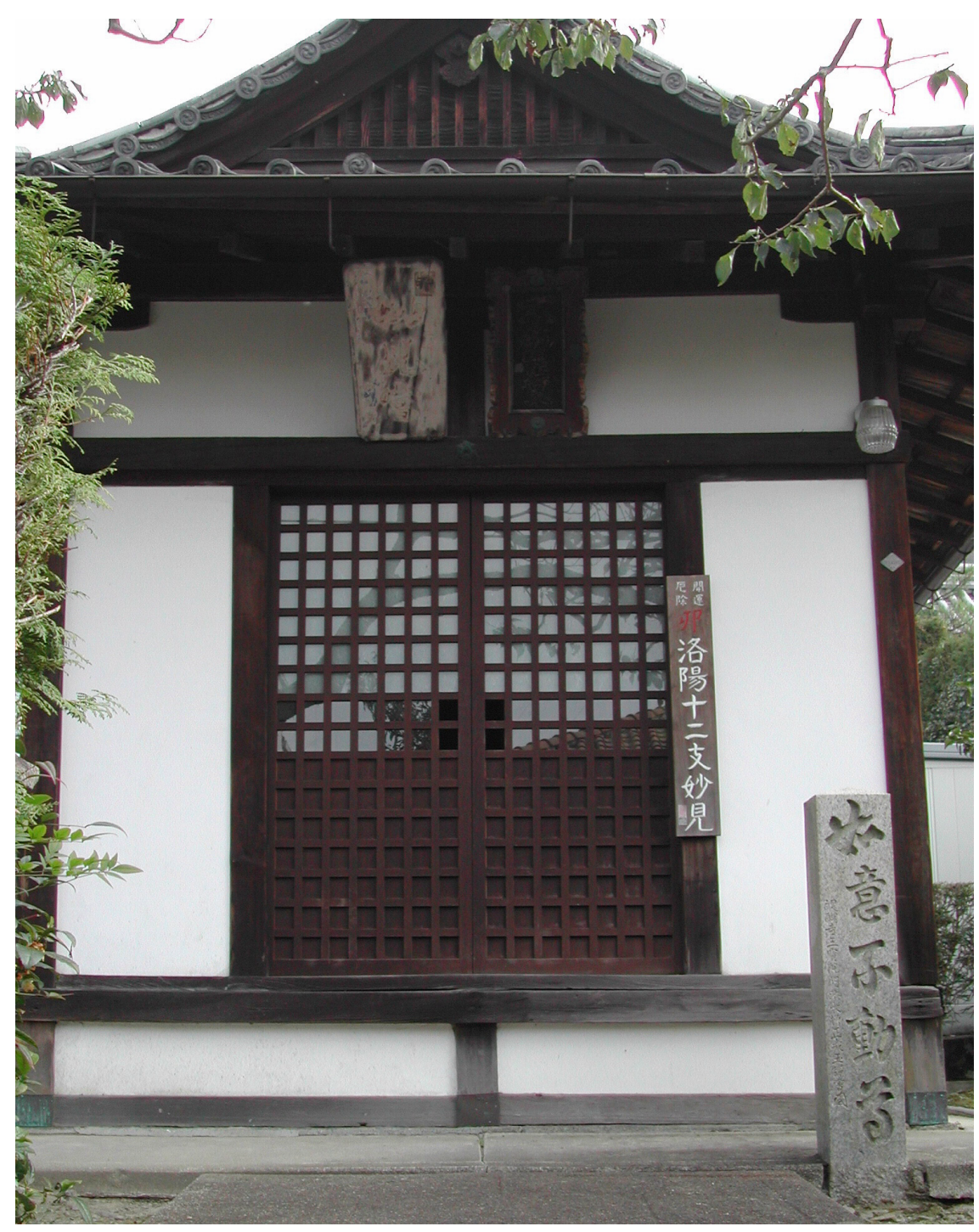

Culture and Cosmos 
36 The Worship of Celestial Bodies in Japan

Fig. 14a The first and second torii that mark the entrance to Seimei Shrine, Kyoto.

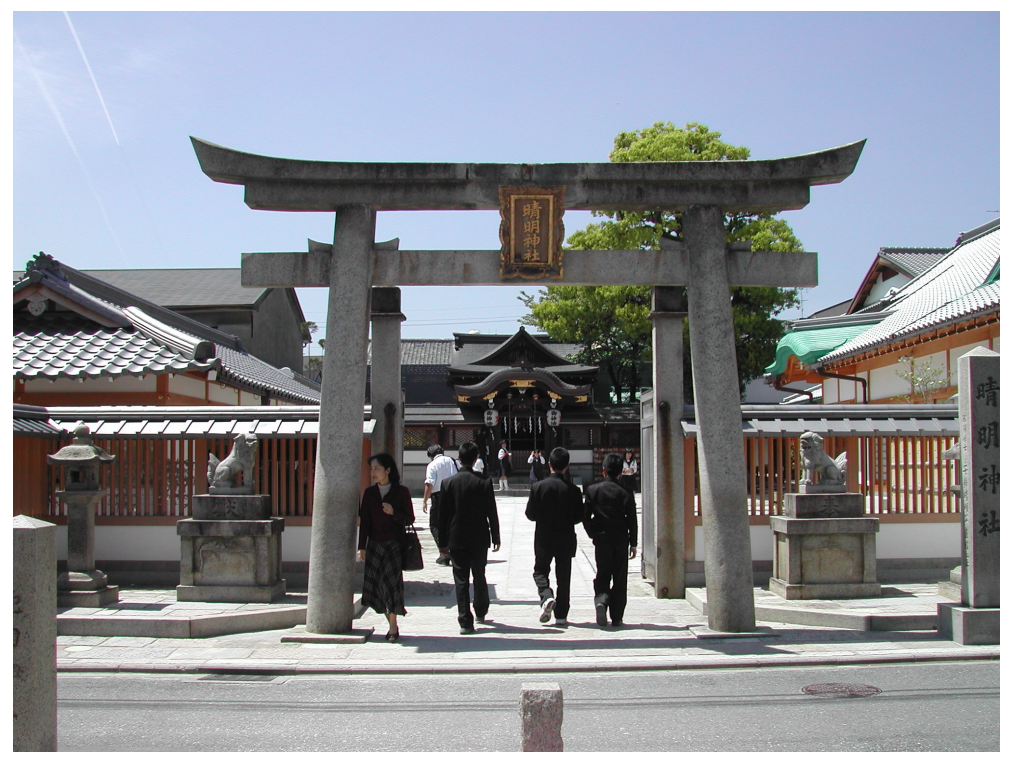

Fig. 14b The main hall of the Seimei Shrine with two worshippers.

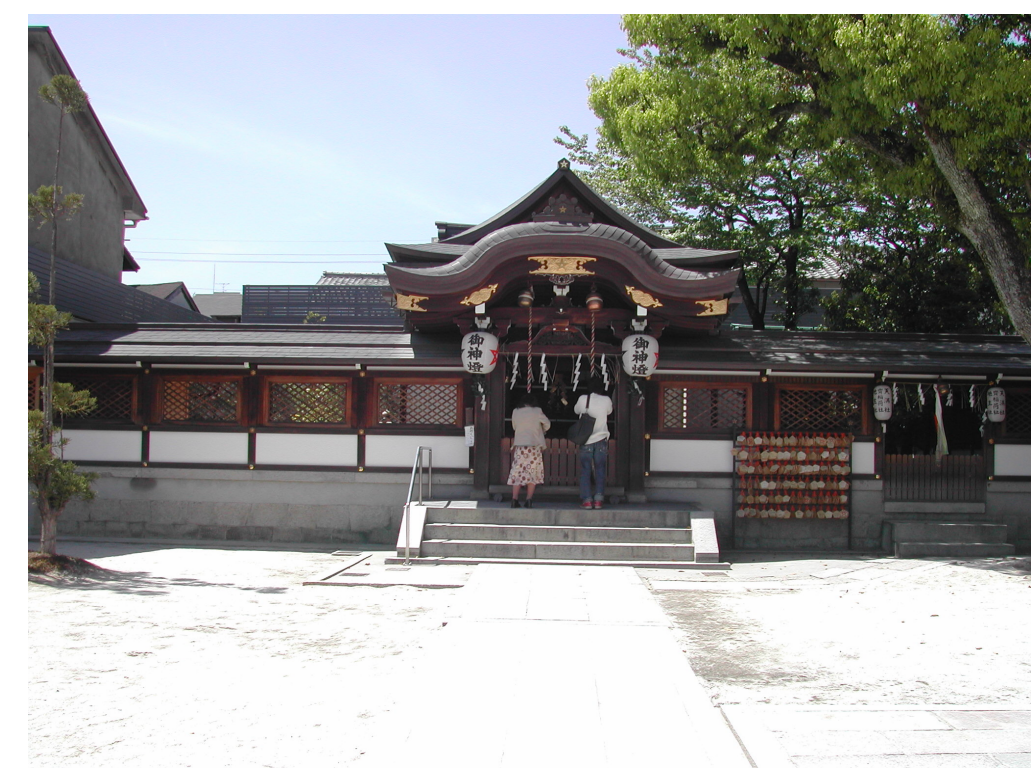

Culture and Cosmos 
Fig. 15a Detail of the red five-pointed star pattern on the votive lanterns of the main hall at Seimei Shrine. On the right is the hanging place for votive tablets.

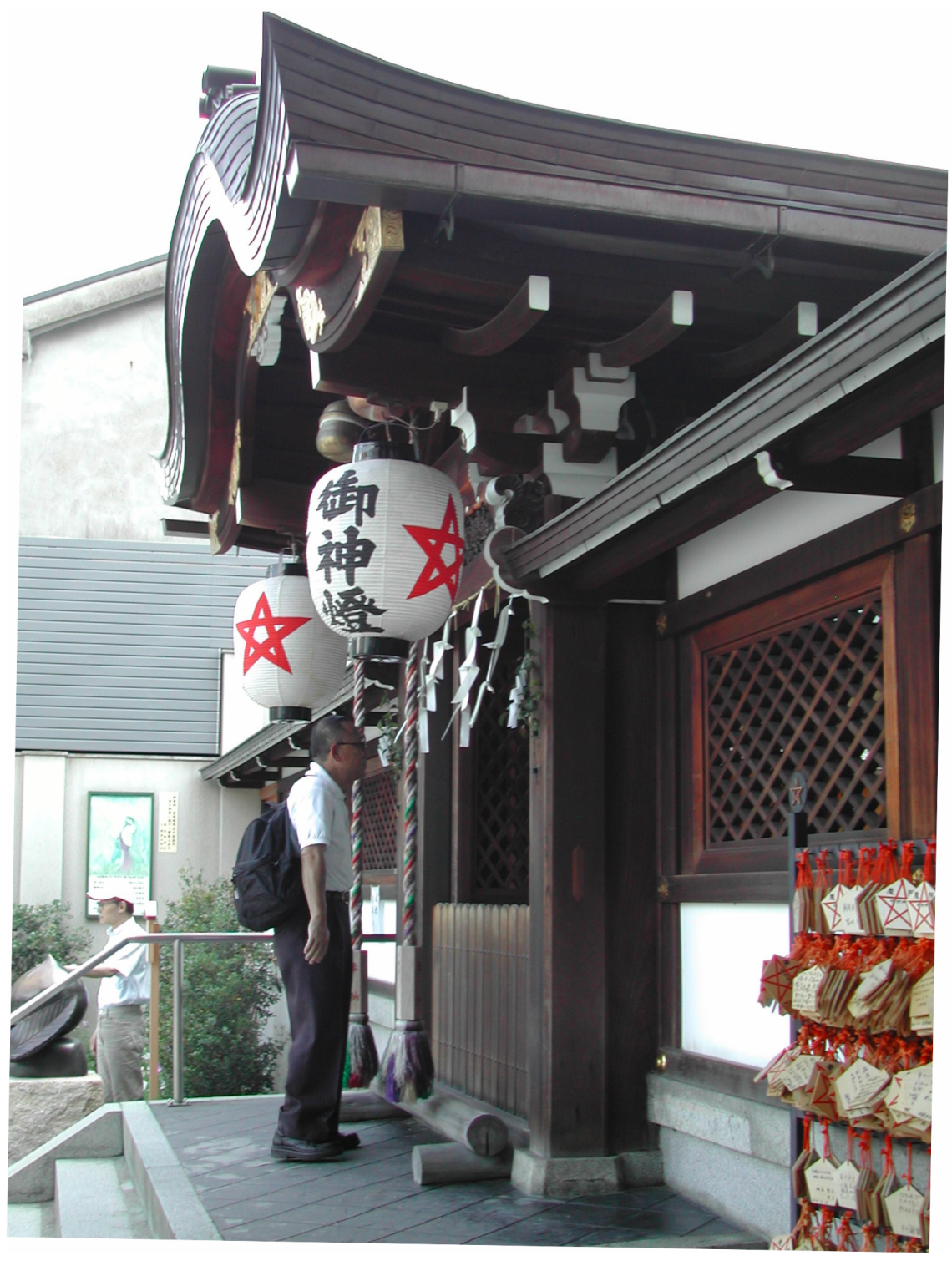

Culture and Cosmos 
38 The Worship of Celestial Bodies in Japan

Fig. 15b A wooden votive tablet ( $\mathrm{ema}$ ) with the red five-pointed star, sold at Seimei Shrine.

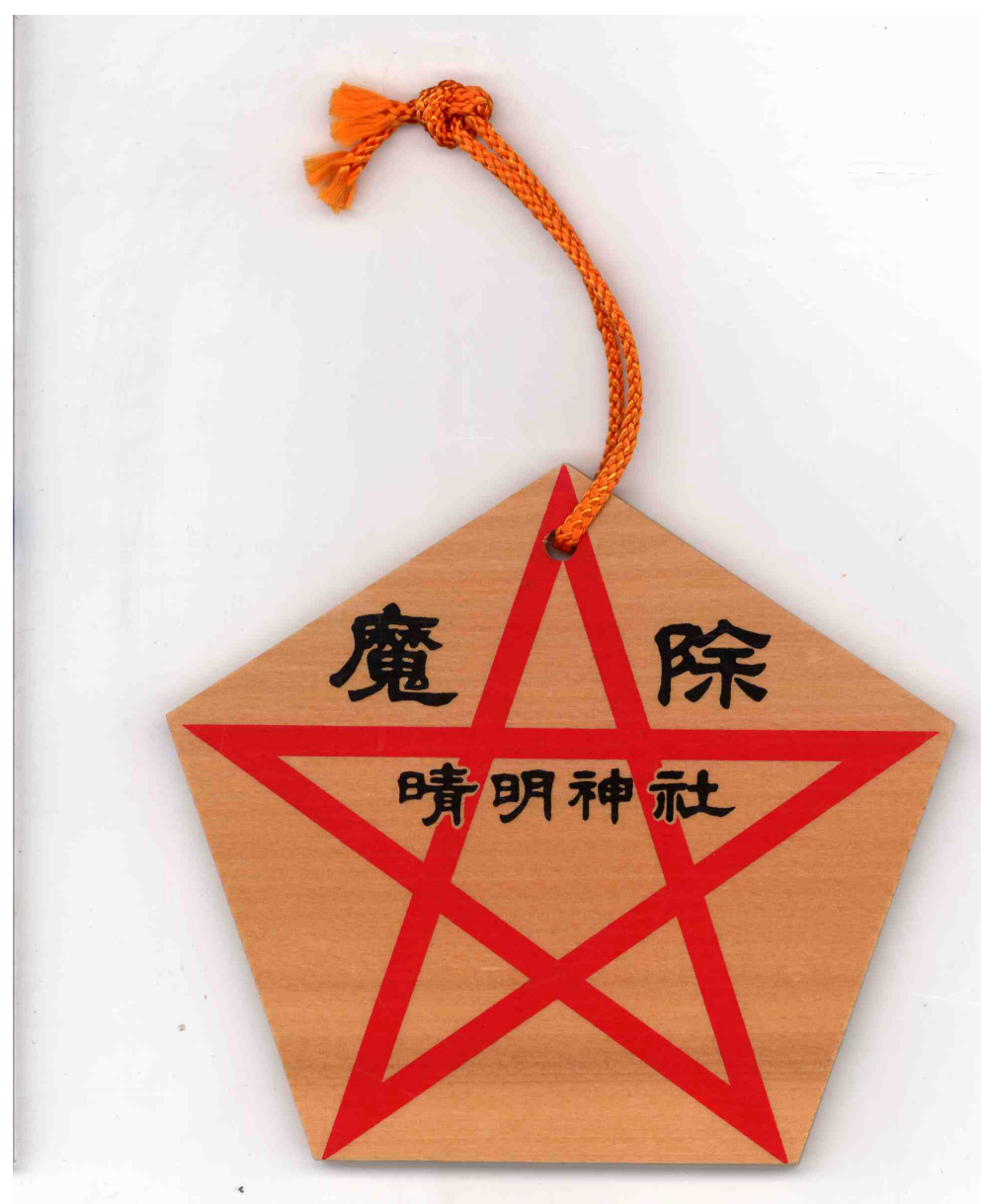

Culture and Cosmos 
Fig. 16 Poster advertising Onmyōji II, the second film devoted to Abe no Seimei, in the Seimei Shrine compounds.

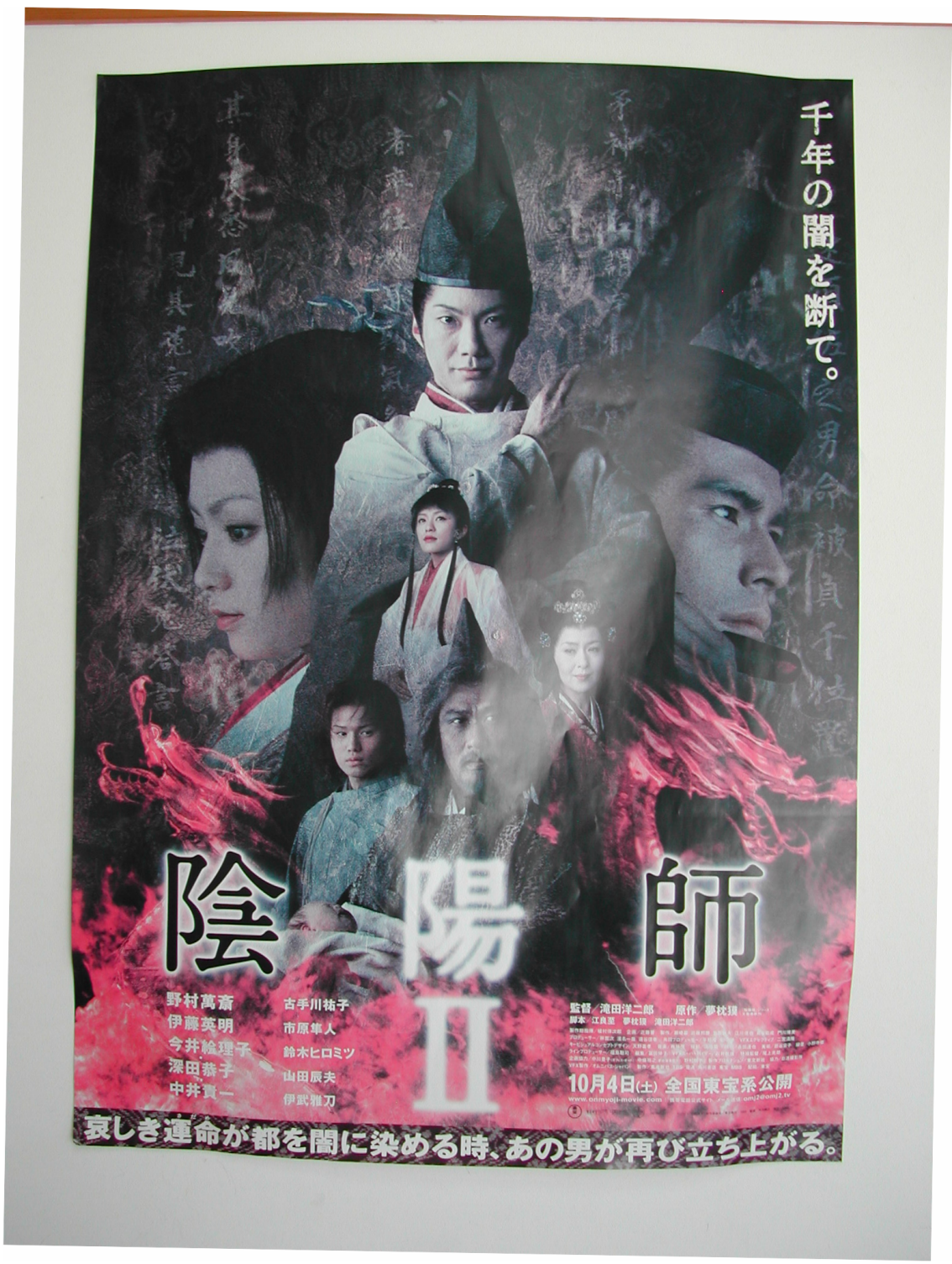

Culture and Cosmos 
40 The Worship of Celestial Bodies in Japan

Fig. 17 Notepads with divinatory talismans (a) and other goods with the star mark (b) sold near Seimei Shrine.
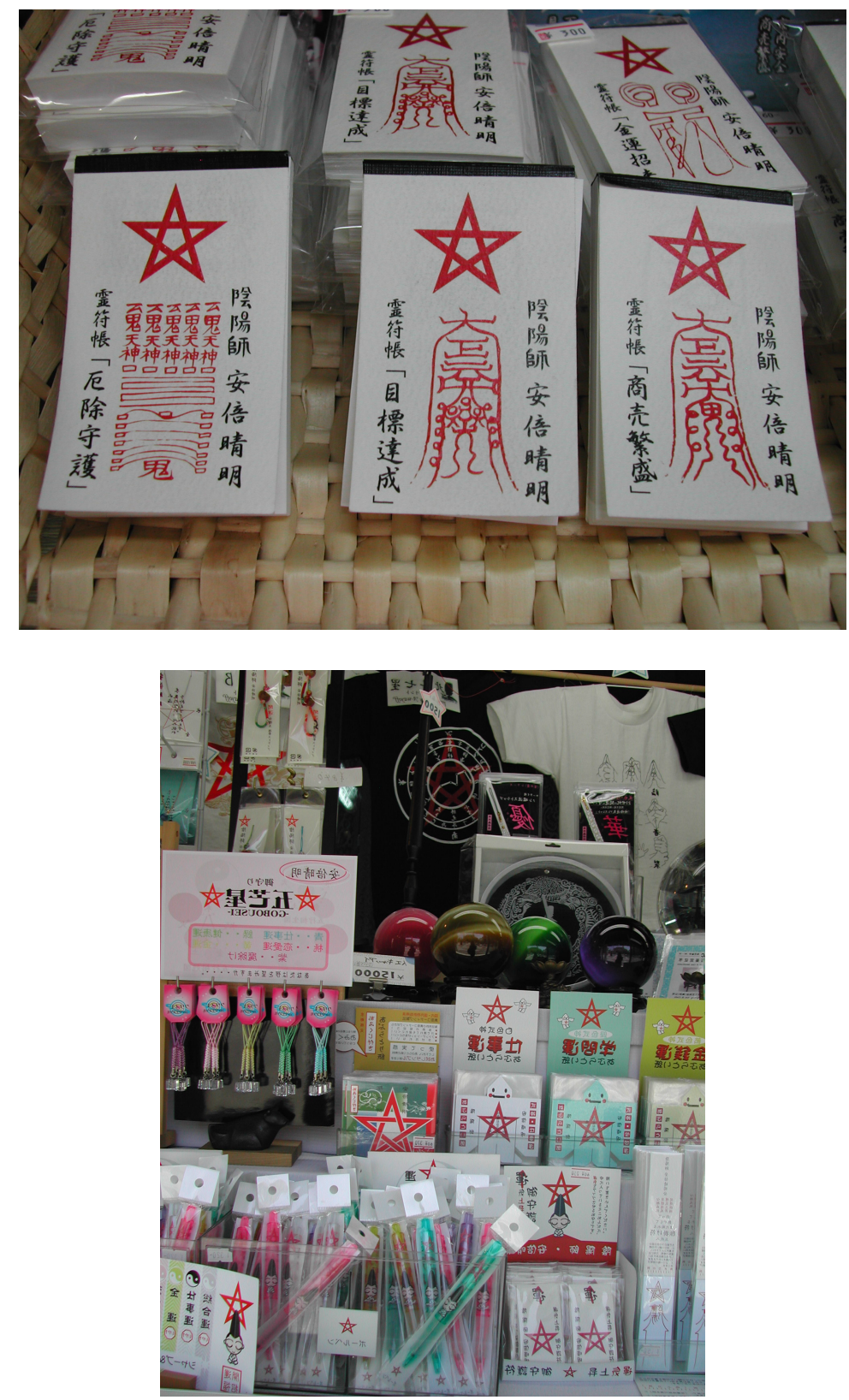

Culture and Cosmos 
Fig. 18 An edition of the traditional calendar (koyomi) for 2006, compiled by a member of the Japanese Society for the Traditional Calendar.

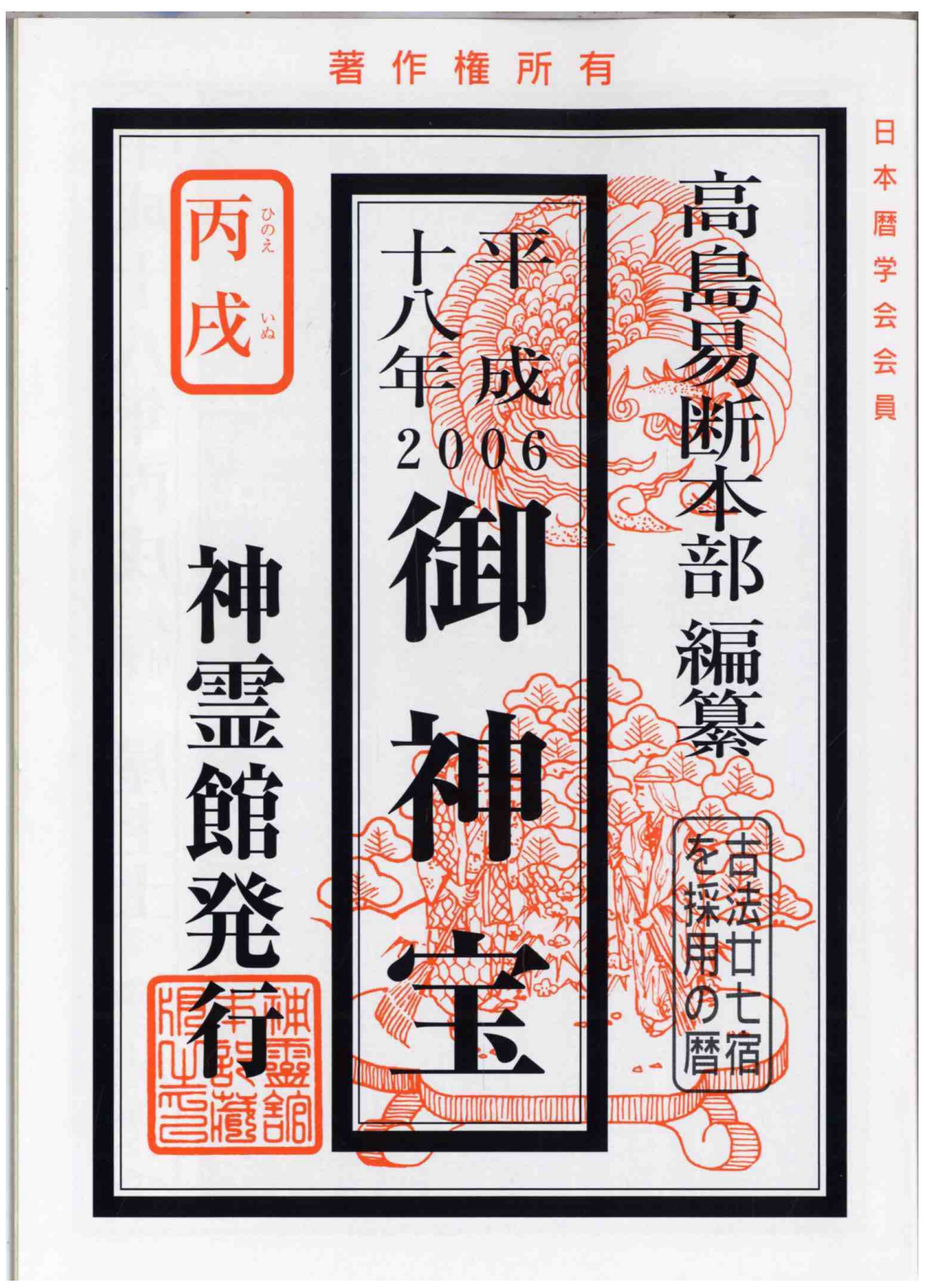

Culture and Cosmos 
42 The Worship of Celestial Bodies in Japan

Fig. 19a Drawing of the ritual platform for a fire service (goma) dedicated to the Big Dipper. From a $13^{\text {th }}$ century ritual manual, Fujii Eikan Archives. Courtesy of Art Research Centre, Ritsumeikan University.

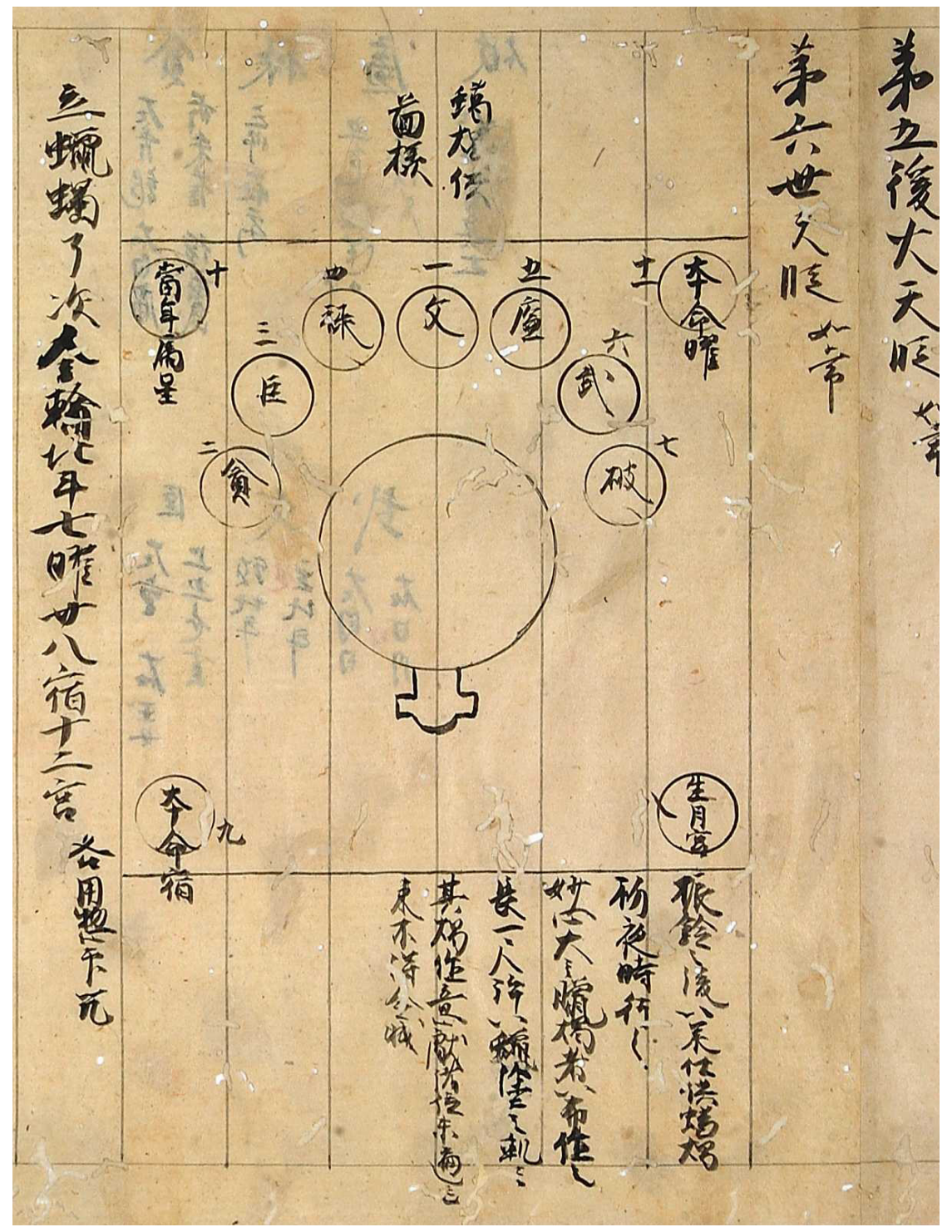

Culture and Cosmos 
Fig. 19b Chart of the Big Dipper with the names of the seven stars of the Big Dipper (right) and of the five Polar stars (left). Later annotation (in red) adds alternative names for the seven stars. From a $13^{\text {th }}$ century ritual manual, Fujii Eikan Archives. Courtesy of Art Research Centre, Ritsumeikan University.

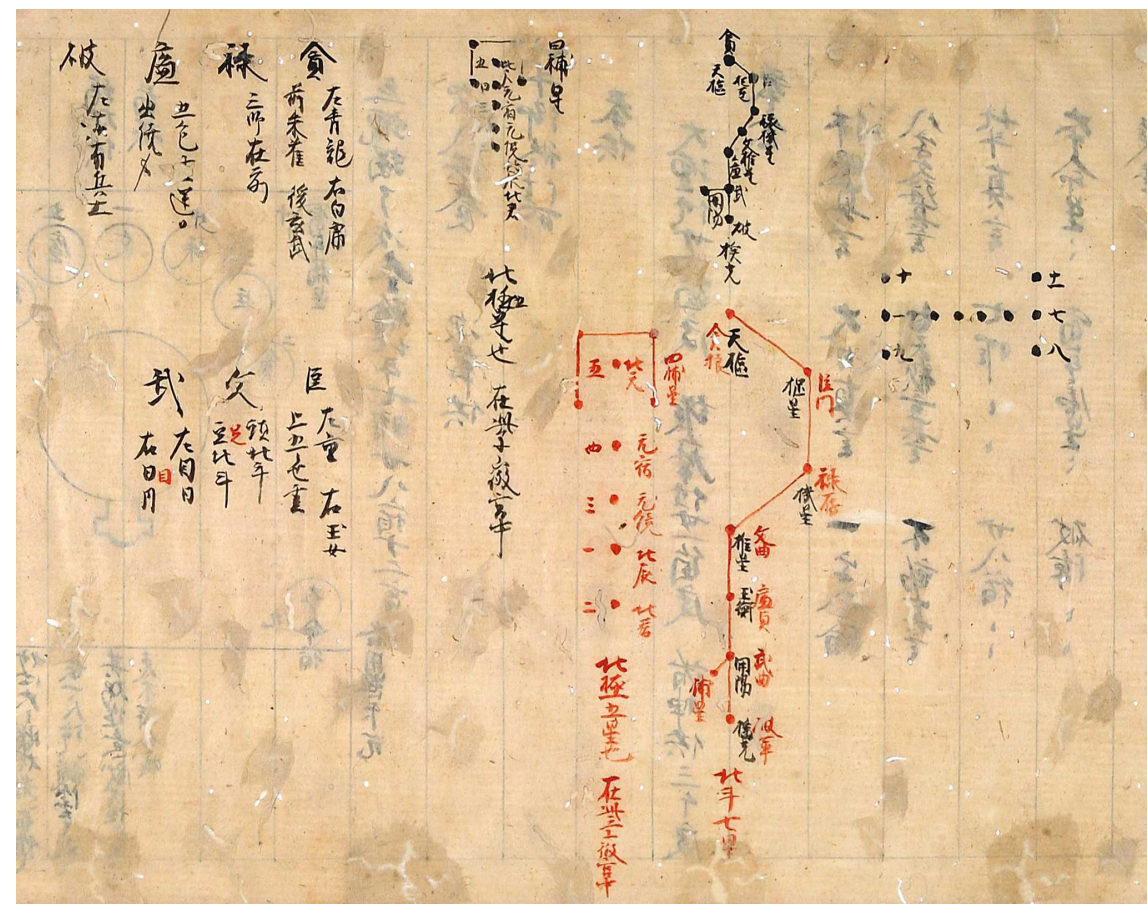

